\title{
Circulation and exchange in a broad Arctic fjord using glider-based observations
}

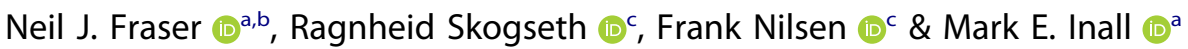 \\ aThe Scottish Association for Marine Science, Scottish Marine Institute, Oban, UK; ' $T$ The Department of Geosciences, University of \\ Edinburgh, Grant Institute, Edinburgh, UK; 'Department of Arctic Geophysics, The University Centre in Svalbard, Longyearbyen, Norway
}

\section{ABSTRACT}

In recent years, Svalbard fjords have experienced a substantial reduction in winter sea-ice extent. This has been linked to changes in wind stress patterns over Fram Strait and an increased transport of warm Atlantic Water into the fjords. In November 2014, we deployed two Slocum gliders to Isfjorden and measured the hydrographical properties and depthaveraged currents in the region. The campaign marked the first time gliders have been used inside an Arctic fjord. We observed geostrophically balanced flow patterns both in the mouth, where the heat flux into the fjord was calculated to be $0.13 \mathrm{TW}$, and in the interior of Isfjorden, where geostrophic flows were up to $20 \mathrm{~cm} \mathrm{~s}^{-1}$. After a change in the prevailing wind direction on the West Spitsbergen Shelf, we found evidence for a wind-driven geostrophic control mechanism at the fjord mouth, impeding fjord-shelf exchange, and found that the geostrophic circulation inside the fjord had broken down. We conclude that the circulation patterns in Isfjorden are heavily influenced by rotational effects and by wind activity both locally and on the West Spitsbergen Shelf, and that geostrophically balanced exchange flows may deliver Atlantic Water to the fjord interior given the correct conditions at the fjord mouth. The combination of hydrography and high-resolution velocity data from throughout the Isfjorden region provided new insights into the circulation here, suggesting that this approach will be useful for studying high-latitude fjords in the future.

\section{KEYWORDS}

Geostrophic circulation; shelf exchange; Svalbard; robotics; sea ice; polar oceanography

\section{ABBREVIATIONS}

ArW: Arctic Water; AW: Atlantic Water; CTD: conductivity, temperature and depth sensor; DAC: depth-averaged current; IW: Intermediate Water; SPC: Spitsbergen Polar Current STC: Spitsbergen Trough Current; WSC: West Spitsbergen Current; WSS: West Spitsbergen Shelf;

TAW: Transformed Atlantic Water

\section{Introduction}

High-latitude fjords are the link between the ocean and glaciers. They act as heat sinks for subtropical waters travelling poleward and, because of glacial runoff and melting, have a freshening influence on the polar oceans (Murray et al. 2010; Straneo \& Heimbach 2013). Circulation within these small, restricted regions has a unique control over the distribution of ocean heat to glaciers. Differences in geometry and location cause fjords to behave differently so that heat and salt exchange is highly dependent on the circulation scheme within a given fjord. Ocean dynamics in Arctic fjords are generally controlled by freshwater input, tides, the atmosphere, the Earth's rotation, shelf exchange and sea-ice cover (Skogseth et al. 2004; Nilsen et al. 2008; Cottier et al. 2010; Inall \& Gillibrand 2010). Together, these forcings determine the extent of any vertical and horizontal circulation of water masses. The presence of seasonal ice cover means that the relative importance of the other forcings varies throughout the year, especially in the case of wind stress, which is strongly suppressed in the winter. The buoyancy of the surface layer is affected by salt release during freezing in winter, resulting in convective overturning and mixing of the water column, while the opposite process occurs in summer when melting, runoff and iceberg calving bring fresh water into the fjord and increase the stratification (Cottier et al. 2010). Under ice, vertical mixing is sustained by tides and freshwater runoff, both of which generate shear between layers in the water column, and momentum fluxes at the fjord boundaries. However, during ice-free periods, the upper layer circulation in a two-layered fjord is shown to be dominated by the wind (Skogseth et al. 2007). The steep-sided topography of fjords causes the wind direction to be mainly down- or up-fjord, either enhancing or impeding the estuarine outflow of the surface water, while acting to homogenize the upper layer through vertical mixing.

Winter sea-ice extent around Svalbard has decreased significantly in recent years, including the interior of Svalbard's fjords (Pavlov et al. 2013; Onarheim et al. 2014; Muckenhuber et al. 2016). This has been linked to an increased transport of warm AW $\left(\Theta>3^{\circ} \mathrm{C}, 35.1<S_{A}<35.4 \mathrm{~g} / \mathrm{kg}\right)$ into the fjords caused by changes in the prevailing winds on the shelf (Cottier et al. 2007; Nilsen et al. 2008, 
Nilsen et al. 2016). As calving and melting of Svalbard's tidewater glaciers coincides with increased AW transport (Luckman et al. 2015), fjordic circulation is also key parameter in understanding sea-level rise. Further observations of the currents within these fjords would allow a richer understanding of the dynamics of AW inflow.

Several current systems are present in the Svalbard region. A northward travelling slope current, the WSC, transports AW into the region along the shelf break (Fig. 1). A geostrophically balanced branch of the WSC has been modelled meandering into the troughs on the WSS, termed the STC (Nilsen et al. 2016). A coastal surface current, the SPC, brings ArW $\left(\Theta<1^{\circ} \mathrm{C}, 34.5<S_{A}<35 \mathrm{~g} / \mathrm{kg}\right)$ around the southern end Spitsbergen from Storfjorden and the Barents Sea. All water masses are defined in Table 1.

Isfjorden is the largest fjord on the west coast of Spitsbergen. It includes four side-fjord systems: Grønfjorden and Adventfjorden on the southern side; Sassenfjorden that leads to Tempelfjorden and Billefjorden; and Nordfjorden leading to Dicksonfjorden and Ekmanfjorden (Fig. 1). Several tidewater glaciers terminate in the Isfjorden system (generally in the northern and eastern side-fjords) which have accelerated and thinned in recent decades in keeping with the wider trend across Svalbard (Nuth et al. 2010, Nuth et al. 2013). Isfjorden does not have a sill at its mouth and a $250 \mathrm{~m}$ deep trough (Isfjordrenna) runs across the shelf from the mouth to the shelf break. It is therefore well connected to the WSS and slope area, allowing dense AW from the WSC access to the fjord. The mouth of Isfjorden is $10 \mathrm{~km}$ wide (Nilsen et al. 2008), while inside the width increases to over $20 \mathrm{~km}$. Cottier et al. (2010) estimated the internal Rossby radius, $L_{R}$, to be approximately $3.6-6 \mathrm{~km}$ for typical Svalbard fjords.
Isfjorden can therefore be considered a broad fjord, and we expect rotational effects to be important.

Previous studies of the circulation in Isfjorden have focused on the trough and mouth area where the exchange of coastal water and fjord water occurs. On the basis of the results from the I1 current meter mooring (Fig. 2) and CTD stations in the mouth and shelf areas of Isfjorden, the STC and SPC have been found to circulate into the mouth region of Isfjorden. Analyses of year-round current measurements show seasonality such that the STC is stronger in the winter and early spring than in summer and autumn, and recent modelling results link the extent of STC penetration into the fjord mouth to large-scale wind forcing (Nilsen et al. 2016). On the shelf, southerly winds act to converge the surface layer in the SPC waters against the coast, raising sea-level height and causing down welling of the pycnocline. This deepens the SPC, which circulates across the Isfjorden entrance to form a barrier between shelf and fjord. Sea-surface tilt over the shelf break is increased, accelerating the barotropic WSC and shifting it eastward, forcing the STC to follow shallower isobaths on the shelf and hence enhancing AW/TAW transport towards the fjord mouth (Nilsen et al. 2016). Under these conditions

Table 1. Definitions used for the classification of water masses during the study. $\Theta$ denotes conservative temperature. $S_{A}$ denotes absolute salinity while $S_{P}$ denotes practical salinity.

\begin{tabular}{llllc}
\hline Water mass & Abbreviation & $\Theta\left({ }^{\circ} \mathrm{C}\right)$ & $\mathrm{S}_{A}(\mathrm{~g} / \mathrm{kg})$ & $\mathrm{S}_{P}(\mathrm{psu})$ \\
\hline Atlantic Water & AW & $3.0-7.0$ & $35.1-35.4$ & $34.9-35.2$ \\
$\begin{array}{l}\text { Transformed Atlantic } \\
\quad \text { Water }\end{array}$ & TAW & $1.0-3.0$ & $34.9-35.1$ & $34.7-34.9$ \\
$\begin{array}{l}\text { Surface Water } \\
\text { Intermediate Water }\end{array}$ & SW & $1.0-7.0$ & $30.1-34.2$ & $30.0-34.0$ \\
Arctic Water & ArW & $>1.0$ & $34.2-34.9$ & $34.0-34.7$ \\
\hline
\end{tabular}

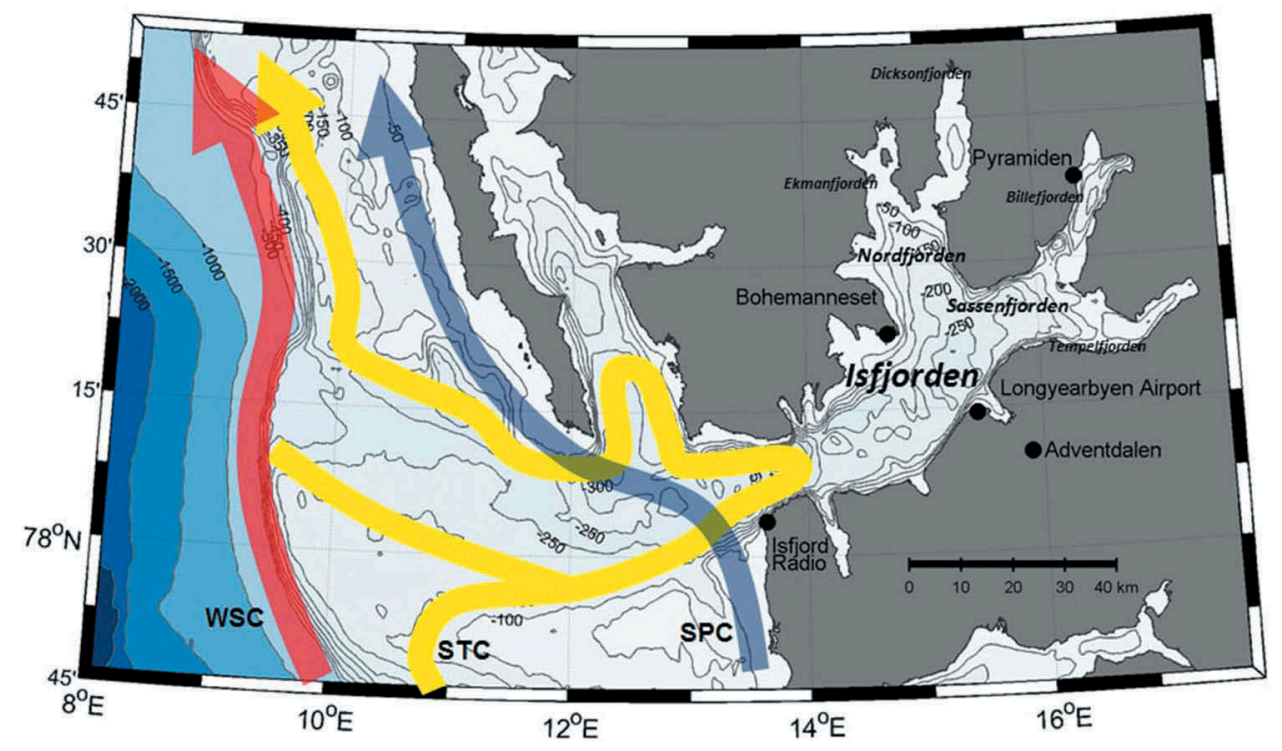

Figure 1. A map of Isfjorden and adjacent shelf region. All fjords are labelled in italics while black dots mark local weather stations. The WSC is shown by a red arrow, the SPC is shown in blue and the STC is shown in yellow. 
the deep layer AW and TAW have restricted access to the fjord because of geostrophic control, a mechanism whereby the barotropic currents on the shelf are prevented from circulating beyond the fjord mouth on account of large horizontal density gradients between fjord and shelf (Klinck et al. 1981). The STC, effectively blocked off from the fjord interior by the SPC, instead circulates around the fjord mouth before continuing northwards along isobaths on the shelf. This mechanism has been previously described both in Isfjorden (Nilsen et al. 2008; Nilsen et al. 2016) and other broad fjords in west Spitsbergen (Svendsen et al. 2002; Cottier et al. 2005). In contrast, northerly winds cause a divergence of the surface layer near the coast. This diminishes sea surface tilt, weakening the barotropic pressure field which drives the WSC, and drives an upwelling of the pycnocline, increasing heat content of the water column on the shelf (Nilsen et al. 2016). Off-shore Ekman transport acts to diminish the geostrophic control mechanism by flattening out the isopycnals between the SPC and the deeper STC circulating in the mouth, which opens the door to rapid deep layer exchange flows between fjord and shelf. Hence, through differing mechanisms, both northerly and southerly winds can increase heat flux towards Isfjorden from the shelf break. There is a relatively sparse literature on circulation and exchange in broad fjords (Ingvaldsen et al. 2001; Svendsen et al. 2002; Janzen et al. 2005; Skogseth et al. 2005; Johnson et al. 2011; Inall et al. 2014; Inall et al. 2015; Carroll et al. 2017; Sundfjord et al. 2017), and it is unclear how the circulation within Isfjorden, as a broad fjord, interacts with the exchange mechanism described above, which is applicable regardless of fjord width.

The objectives of this paper are to (1) classify the dominant circulation within Isfjorden, (2) quantify the exchange of heat between fjord and shelf and (3) study the effect of changing large-scale atmospheric forcing on the circulation and hydrography of the Isfjorden interior, extending the current understanding beyond the shelf and mouth regions. To this end we deployed two Slocum gliders to Isfjorden in November 2014, which profiled the salinity and temperature of the water and also provided measurements of the DACs in the fjord. These data were combined to calculate the absolute geostrophic velocity fields in cross-fjord sections, giving an insight into the vertical current structure. The glider data was supplemented by atmospheric data from both local weather stations and an atmospheric model. While gliders have previously been used in a fjord mouth region (Bachmayer et al. 2007), the survey marked the first time that gliders have been operated within a fjordic system. Unlike the existing mooring data, gliders provide velocity data with a spatial aspect, providing a new insight into the circulation patterns in Isfjorden.

\section{Methods}

\section{The Slocum glider}

Gliders are autonomous, buoyancy-driven, underwater vehicles used to profile the physical and chemical properties of the water column. They were first detailed in Doug Webb's lab book in 1986 and publicized in 1989 by Henry Stommel (Stommel 1989). A number of different gliders have been developed and used by various organizations; the two gliders that were operated in Svalbard are Slocum gliders. A Slocum glider is a $1.8 \mathrm{~m}$ long, torpedo-shaped, winged autonomous underwater vehicle. It has a forward speed of $20-30 \mathrm{~cm} \mathrm{~s}^{-1}$ and it propagates with a saw tooth-shaped gliding trajectory of up to $1000 \mathrm{~m}$ depth, surfacing between dives. Forward propulsion is derived through a combination of buoyancy change and pitch-angle adjustment, and steering by means of a tail fin rudder. The navigation system uses an on-board GPS receiver coupled with an altimeter sensor and magnetic compass, and back-up positioning and communications are provided by an Argos transmitter. The two-way communications with the vehicle are maintained by RF modem or the global satellite phone service Iridium. All antennas are located within the tail fin, which is raised out of the water when the vehicle surfaces. As a power source the glider uses either alkaline or lithium batteries, but the energy consumption is highly dependent on the amount of sensors, the sampling frequency, the diving depth, the stratification and how often the glider surfaces. The duration of one mission may therefore vary from approximately 20 days up to one year. Gliders can be equipped with several sensors depending on the project in question. The default sensors measure depth, conductivity and temperature. In addition, gliders can be used as platforms for current meters, turbulence instruments, and sensors to measure the optical properties of water. DAC measurements are provided for each dive. When a glider surfaces, it uses GPS to determine its position and can compare this to the position at which it is expected to surface through the use of 'dead-reckoning' (based on an internal magnetic compass and velocity through the water). The difference between these positions can be attributed to horizontal advection, and therefore used to calculate current velocities. The DAC is intrinsically depth-averaged as a consequence of the fact that the gliders only have accurate positional data when on the surface. 


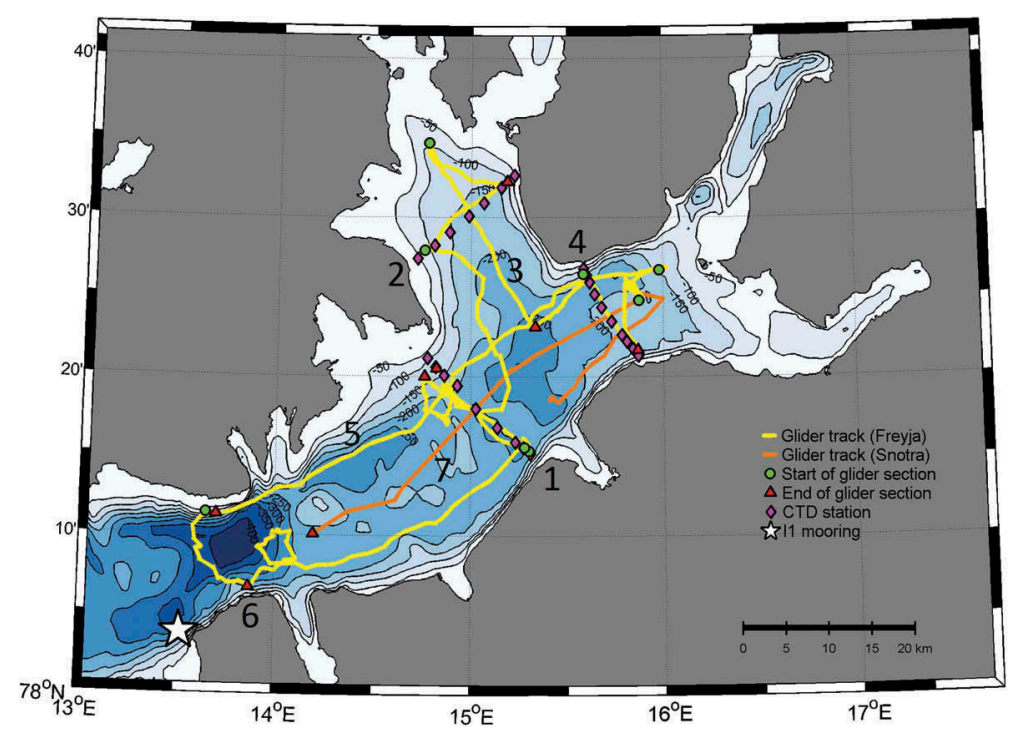

Figure 2. The paths of the two Slocum gliders operated in Isfjorden, Svalbard, in November 2014 are shown as yellow and orange lines. Green circles (red triangles) show the start (end) of sections, with section number shown in black. Purple diamonds show CTD locations and the 11 mooring location is marked by a white star.

This relies on the assumption that a glider moves at a constant vertical velocity and hence spends equal time at each depth level. Merckelbach et al. (2008) estimated that, due to possible poor calibration of the sensors and the glider's calculation method, the error in DAC data may be up to $2-3 \mathrm{~cm} \mathrm{~s}^{-1}$.

Table 1 contains the full list of sensors that were used during the Isfjorden mission, the accuracies given here provided by the sensor manufacturers. The two gliders carried additional oxygen, fluorescence, chlorophyll $a$ and turbidity sensors. Glider CTDs and navigation systems were last calibrated in October/November 2011 and January 2012, respectively. More details about gliders and their operation are available in Schofield et al. (2007).

\section{Mission summary}

A Slocum glider, called 'Freyja' (a Slocum G1 1000M, unit 105), was deployed on 7 November 2014 around the entrance to Adventfjorden, embarking on a comprehensive survey of the Isfjorden area over the following three weeks. Figure 2 shows the path taken by the gliders during the survey, while Table 2 details the location, start time and end time of each section. The glider took a transverse section of Isfjorden (Section 1) before entering Nordfjorden, where it took two

Table 2. Sensors used during the glider mission in Isfjorden and their accuracies.

\begin{tabular}{lllc}
\hline Parameter & \multicolumn{1}{c}{ Sensor } & Manufacturer & Accuracy \\
\hline Conductivity & SBE-41 CTD & Sea-Bird & $\pm 0.005 \mathrm{~g} / \mathrm{kg}$ \\
Temperature & SBE-41 CTD & Sea-Bird & $\pm 0.002^{\circ} \mathrm{C}$ \\
Pressure & SBE-41 CTD & Sea-Bird & $\pm 2 \mathrm{db}$ \\
Oxygen & Optode 3835 & Aanderaa & $8 \mu \mathrm{M} \mathrm{or} 5 \%$ \\
Turbidity & ECO-FLNTU & Wet Labs & $0.01 \mathrm{NTU}$ \\
Chlorophyll $a$ & ECO-FLNTU & Wet Labs & $0.025 \mu \mathrm{g} \mathrm{I}^{-1}$ \\
\hline
\end{tabular}

sections, one across-fjord (Section 2) and one alongfjord (Section 3). It then took a cross-section of Sassenfjorden (Section 4) before taking a section along the north side of Isfjorden (Section 5). For this section it was joined by 'Snotra' (a Slocum G1 $1000 \mathrm{M}$, unit 081 ), a second Slocum glider, which was deployed on 13 November 2014, also around the entrance to Adventfjorden, before heading towards the head of Isfjorden. Once there, Snotra took a section along the centre of Isfjorden, southward of that taken by Freyja (Section 7). The intention was to continue this trajectory out onto the WSS region; however, Snotra detected a leak near the mouth of Isfjorden and had to be recovered early. Section 7 data contains a gap as a result of this malfunction. Finally, Freyja covered the mouth area of Isfjorden with a cross-section (Section 6) and then returned to retrace Section 1 (hereafter Section 1b). Freyja and Snotra were rated to a depth of $200 \mathrm{~m}$ and $1000 \mathrm{~m}$, respectively.

\section{CTD sections}

The hydrography data from the Slocum gliders were complemented by ship-based CTD profiles taken using the Sea-Bird Electronics SBE19plus V2 CTD. Since ship-based CTD sections are generally carried out faster than glider transects, the CTD sections are less influenced by temporal changes and may be considered more synoptic. They were therefore used as a basis of comparison to test the accuracy of the glider hydrography data and hence gauge the usefulness of gliders in a high-latitude fjord environment. The temporal disparity between glider and ship-based hydrography sections was in all cases less than two 
Table 3. Overview of each section taken using either Slocum glider or CTD. Glider section start/end times are rounded to the nearest half hour. For glider sections $n$ is the number of dives while for CTD sections $n$ is the number of casts taken.

\begin{tabular}{|c|c|c|c|c|c|}
\hline Section no. & Instrument & Location & Start time & End time & $n$ \\
\hline 1 & Freyja & Isfjorden mid-fjord & 2014-11-07 19:30 & 2014-11-08 17:05 & 12 \\
\hline 2 & Freyja & Nordfjorden & 2014-11-11 08:25 & 2014-11-12 05:41 & 16 \\
\hline 3 & Freyja & Nordfjorden & 2014-11-12 21:45 & 2014-11-14 14:38 & 27 \\
\hline 4 & Freyja & Sassenfjorden & 2014-11-15 09:05 & 2014-11-16 08:02 & 13 \\
\hline 5 & Freyja & Along Isfjorden & 2014-11-18 19:50 & 2014-11-22 07:05 & 46 \\
\hline 6 & Freyja & Isfjorden mouth & 2014-11-22 07:55 & $2014-11-2300: 50$ & 10 \\
\hline 7 & Snotra & Along Isfjorden & 2014-11-18 12:25 & 2014-11-21 17:35 & 27 \\
\hline $1 b$ & Freyja & Isfjorden mid-fjord & 2014-11-26 13:30 & 2014-11-27 14:30 & 13 \\
\hline 1 (CTD) & SBE19plus & Isfjorden mid-fjord & $2014-11-2009: 51$ & 2014-11-20 14:44 & 8 \\
\hline 2 (CTD) & SBE19plus & Nordfjorden & $2014-11-12$ 12:56 & 2014-11-12 16:48 & 7 \\
\hline 4 (CTD) & SBE19plus & Sassenfjorden & 2014-11-13 15:50 & 2014-11-13 20:50 & 10 \\
\hline
\end{tabular}

weeks, and in most cases two to three days. In order to give context to the time evolution of the hydrography within Isfjorden during the campaign, the November 2014 conditions at Section 1 were compared to CTD sections taken at the same location in both April and September that year.

The SBE19plus was calibrated in March 2012. Section times and locations are given in Table 3, with the locations also marked in Fig. 2.

\section{Atmospheric data}

November 2014 data from five nearby weather stations were compiled in order to study the interaction between fjordic circulation and wind forcing. The stations were located at Isfjorden Radio, Bohemanesset, Longyearbyen Airport, Adventdalen and Pyramiden, shown in Fig. 1, and gave $10 \mathrm{~m}$ wind speed and direction data with a 6-hourly temporal resolution. Isfjord Radio, Longyearbyen Airport and Pyramiden are weather station data delivered from eKlima (www.met.no) while Bohemanneset and Adventdalen are University Centre in Svalbard weather stations. Output $10 \mathrm{~m}$ wind fields from the $2.5 \mathrm{~km}$ resolution AROME-Arctic model (Seity et al. 2011) were interpolated onto the mid-time and midposition of each glider dive so as to compare each DAC measurement to the local wind conditions. The model also was used to provide $2 \mathrm{~m}$ air temperature data which were spatially averaged over the Isfjorden region, taken here as $78-78.5^{\circ} \mathrm{N}, 13-17^{\circ} \mathrm{E}$, and linearly interpolated onto the same 6-hourly time-step as the weather station data.

\section{Glider data}

The DAC values after each dive were assigned to the mid-point between the dive start and end position, essentially collapsing a V-shaped dive onto a single position. This was based around two assumptions: firstly, that horizontal variability is small; and, secondly, that the glider followed an approximately linear course while underwater. The second assumption may not be valid when the glider was navigating a crooked path between sections, but should be reasonably accurate for when the glider was taking straight sections. Vertically sheared currents could also have caused the glider to follow a non-linear path, making this assumption less valid. Because the glider uses a magnetic compass to navigate while underwater, the raw velocity data were referenced to magnetic north rather than geographic north.

Magnetic declination is relatively large in Svalbard and, crucially, varies by around $2^{\circ}$ throughout the region of study. The DAC vectors were therefore each converted into a geographical co-ordinate system using a localized transformation.

In order to later equate the DACs to calculated geostrophic velocities, tidal velocity data were obtained via the Arctic Ocean Tidal Inverse Model (AOTIM-5) (Padman 2004). The model, which describes a barotropic ocean at $5 \mathrm{~km}$ resolution, was used to acquire the tidal velocity components at the mid-point (and mid-time) of each dive (dive displacement was generally less than $1 \mathrm{~km}$ and dive duration was less than 2 hours in all cases). These velocities were then subtracted from the observed depth-averaged velocities in order to eliminate barotropic tidal signal from the data. AOTIM-5 output was compared to barotropic tidal velocities from acoustic Doppler current meters at three different depths $(50,100$, and $200 \mathrm{~m})$ on the I1 mooring near the mouth of Isfjorden (Fig. 2), in order to test the accuracy of the tidal model in the region of study. Tidal analysis of the acoustic Doppler current meter data was performed using the 't_tide' MATLAB package (Pawlowicz et al. 2002). Figure 3 shows that, while the two results are generally in phase, the model significantly and systematically underestimates tidal velocities at the mooring site for November 2014. This may be caused by an intensification of tidal currents near coastal boundaries which is not resolved by the $5 \mathrm{~km}$ model grid. We therefore anticipate residual tidal signal will contaminate the DAC measurement, with the effect likely to be smaller away from coastal boundaries. We proceed with the tidal subtraction method in order to reduce the tidal signal in the DAC data, though it may not eliminate it completely. Uncertainties may also occur as a result of wind-driven dynamics when the glider is on the 

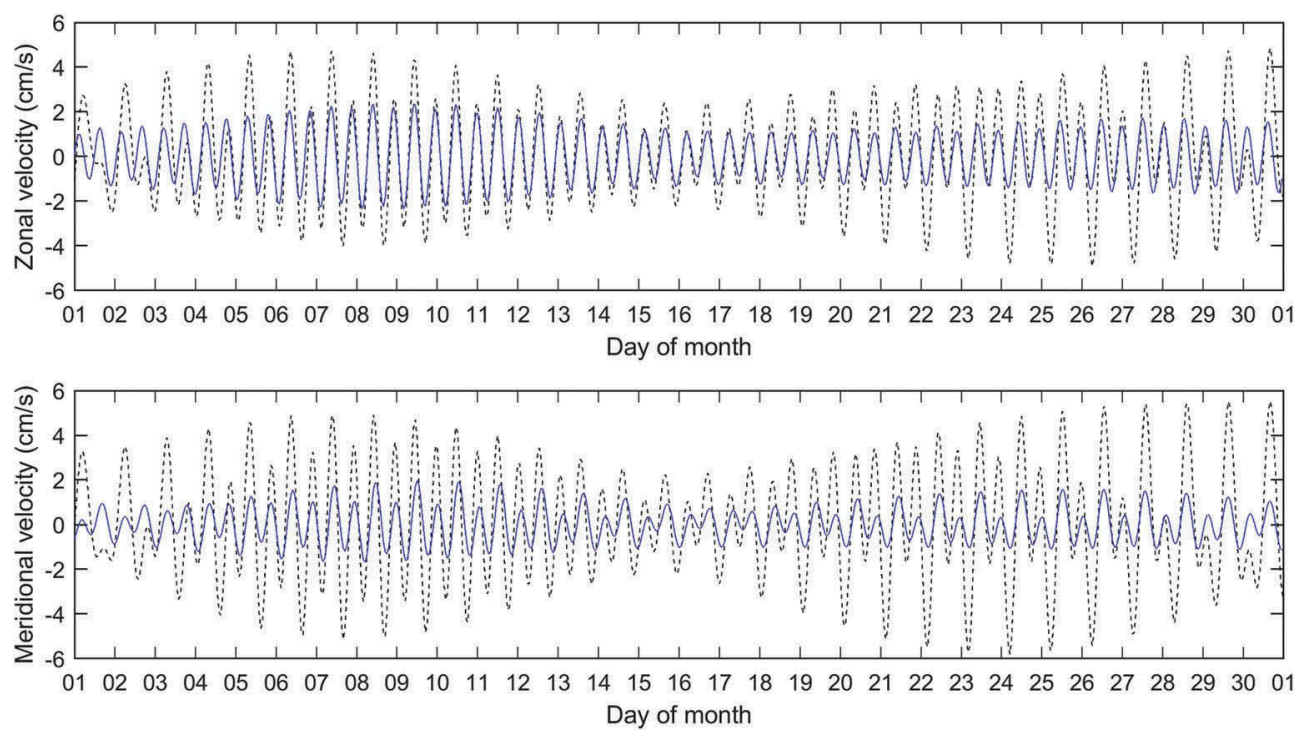

Figure 3. Comparison of AOTIM-5 output (blue) to tidal constituent data from ADCM data (dashed black) at the 11 mooring site, November 2014.

surface. When the glider first surfaces it has no information about its position and must wait for a GPS connection. Hence, the time taken for this connection to be established and the magnitude of the wind stress both contribute to a potential wind bias in the DACs. This time interval was generally around 1 minute and was in all cases less than 2 minutes.

Whenever the pressure reading fell below a given threshold, all hydrographic data were considered to be from the surface and therefore not deemed to be of interest. The threshold pressure was usually $0.2 \mathrm{db}$, but was sometimes adjusted to ensure that all surfacings were registered. Glider CTD lag was corrected according to the methods described in Garau et al. (2011). Absolute salinity, conservative temperature and pressure data from each glider section were interpolated onto a $1 \mathrm{~km} \times 1 \mathrm{~m}$ grid and smoothed at $3 \mathrm{~km} \times 3 \mathrm{~m}$ resolution using Barnes' objective analysis method (Barnes 1994). Some adjustment of the smoothing radii was carried out and we chose the largest smoothing radii that did not remove what we believed to be physical features.

The hydrography fields were used to generate absolute velocity fields. The thermal wind equations, rotated into a fjord-oriented basis (Eqn. 1), shows how vertical shear is a function of the horizontal density distribution.

$$
-f \frac{\partial v}{\partial z}=\frac{g}{\rho_{0}} \frac{\partial \rho}{\partial x}
$$

Here, $x$ indicates the across-fjord coordinate, $z$ is the depth coordinate, $v$ is the along-fjord velocity, $f$ is the Coriolis parameter, $\rho$ is the density and $\rho_{0}$ is the reference density. Integrating over depth yields the geostrophic velocity at each depth level relative to the sea surface velocity (for this calculation we used functions provided in the Gibbs Seawater Oceanographic Toolbox [McDougall \& Barker 2011]). Some adjustment parameter, $v_{\text {ref }}$ is then required in order to find the absolute velocities:

$$
v(x, z)=v^{\prime}(x, z)+v_{\text {ref }}(x)
$$

where we have defined

$$
v^{\prime}(x, z)=\frac{g}{f \rho_{0}} \int_{z}^{0} \frac{\partial}{\partial x} \rho\left(x, z^{\prime}\right) d z^{\prime}
$$

The $v^{\prime}$ fields were referenced using the DACs. The DAC vectors were interpolated onto the same horizontal grid as the geostrophic velocity fields at the surface, and the component perpendicular to the given section, $v^{D A C}$, was used to generate an adjustment parameter, $v_{\text {ref }}$, at each grid location:

$$
v_{r e f}(x)=-\frac{1}{H} \int_{-H}^{0} v^{\prime}(x, z) d z+v^{D A C}
$$

$H$ is the maximum observed depth. The result is a depth-varying velocity field that is calibrated using observed data, giving an insight into the vertical velocity structure. This method includes the barotropic component of the geostrophic flow as the DACs are intrinsically barotropic, but we cannot eliminate ageostrophic terms such as wind stress, bottom drag and any residual tidal signal. We hereafter refer to these fields as absolute velocity.

\section{Results}

\section{Atmospheric data}

Wind vectors for the month of November 2014 are shown in Fig. 4, with the glider and CTD section 


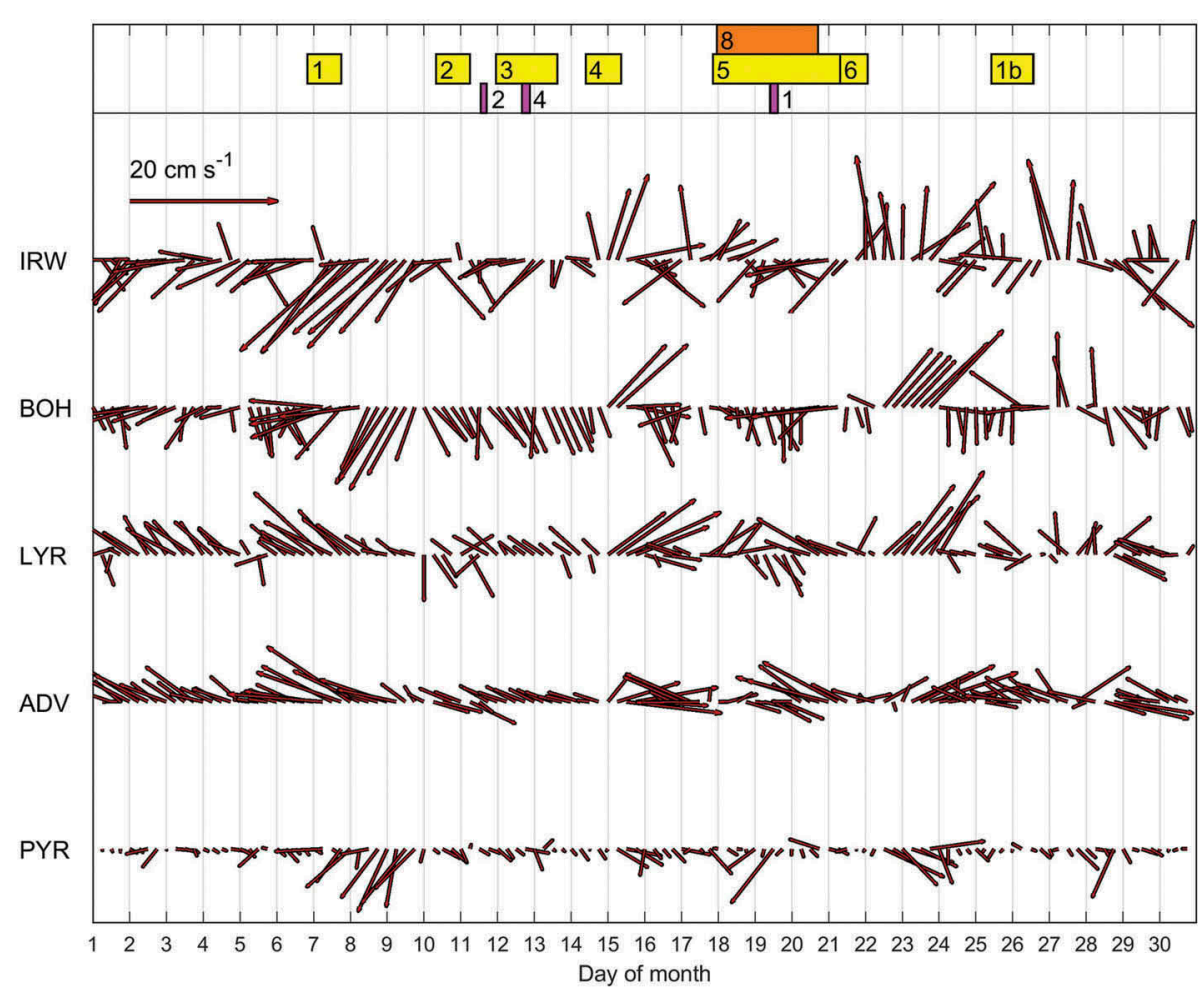

Figure 4. Six-hourly wind velocity time series at Isfjord Radio Station (IRW), Bohe-manneset (BOH), Longyearbyen Airport (LYR), Adventdalen (ADV) and Pyramiden (PYR) for November 2014. The bar along the top of the figure shows the time periods during which sections were being taken, with yellow and orange denoting Freyja and Snotra, and purple denoting CTD.

durations shown along the same timescale. At Isfjord Radio (Fig. 4a), situated on the west coast of Spitsbergen, the prevailing wind direction was from the north during the first half of November. However, after the 15th, this pattern was punctuated by a series of strong southerly winds with increasing regularity, such that from the 22nd onward the prevailing winds were southerlies. Two particularly strong shelf wind events occurred during the study, with strong north-easterlies at Isfjorden Radio between 7 and 9 November, and strong southerlies on the 22nd and 23rd, each with wind speeds of over $15 \mathrm{~m} \mathrm{~s}^{-1}$. Strong southerly wind events also occurred on the 15th and 27th, though these were of shorter duration. The wind events were captured by the other stations situated inland from the coast, with similarly high wind speeds but often in a different direction to those on the shelf on account of topographic steering. Up- and down-fjord are not necessarily 180 degrees out from one another at the stations on headlands. For instance the winds at Longyearbyen Airport were predominately southerly with a shift from south-easterly (down-fjord) to south-westerly (up-fjord) starting on the 15th. During down-fjord winds, the winds at Longyearbyen Airport match those at Adventdalen, indicating that it is affected by wind blowing out of Adventfjorden. The up-fjord winds at the same locations are directed into Isfjorden. At Bohemanneset, the winds were predominately northerly (out of Nordfjorden) prior the 15th, with the south- westerlies (into Isfjorden) in the latter half of the month corresponded to strong southerlies on the shelf. Figure 5 shows the $10 \mathrm{~m}$ wind vectors from the end of each dive, plotted at corresponding glider surfacing times and positions.

The mean of the modelled $2 \mathrm{~m}$ temperature data (Fig. 6) over Isfjorden before 15 November was $-12.6^{\circ}$ $\mathrm{C}$, while after the 15 th this increased to $-5.6^{\circ} \mathrm{C}$. Any temperatures greater than $-2^{\circ} \mathrm{C}$ corresponded to strong southerly shelf winds $\left(>11 \mathrm{~m} \mathrm{~s}^{-1}\right)$.

\section{Hydrography}

Conservative temperature and absolute salinity for corresponding glider and CTD sections are compared in Fig. 7, with all glider hydrography shown in Fig. 8. While Sections 1, 2 and 4 were covered by both the CTD and the glider, they do not always coincide exactly, as ship-based CTD casts were taken around $1 \mathrm{~km}$ closer to shore than the glider can safely operate, and they may have exceeded Freyja's maximum dive depth of $200 \mathrm{~m}$. The hydrographic structure is in good agreement between the ship-based CTD data and corresponding glider data (Fig. 7), particularly at Section 2 where the two transects were taken one day apart. This gives confidence in glider CTD calibration and in the gliders' ability to measure the conditions over cross-fjord sections on a synoptic timescale. However, this may not hold when wind 

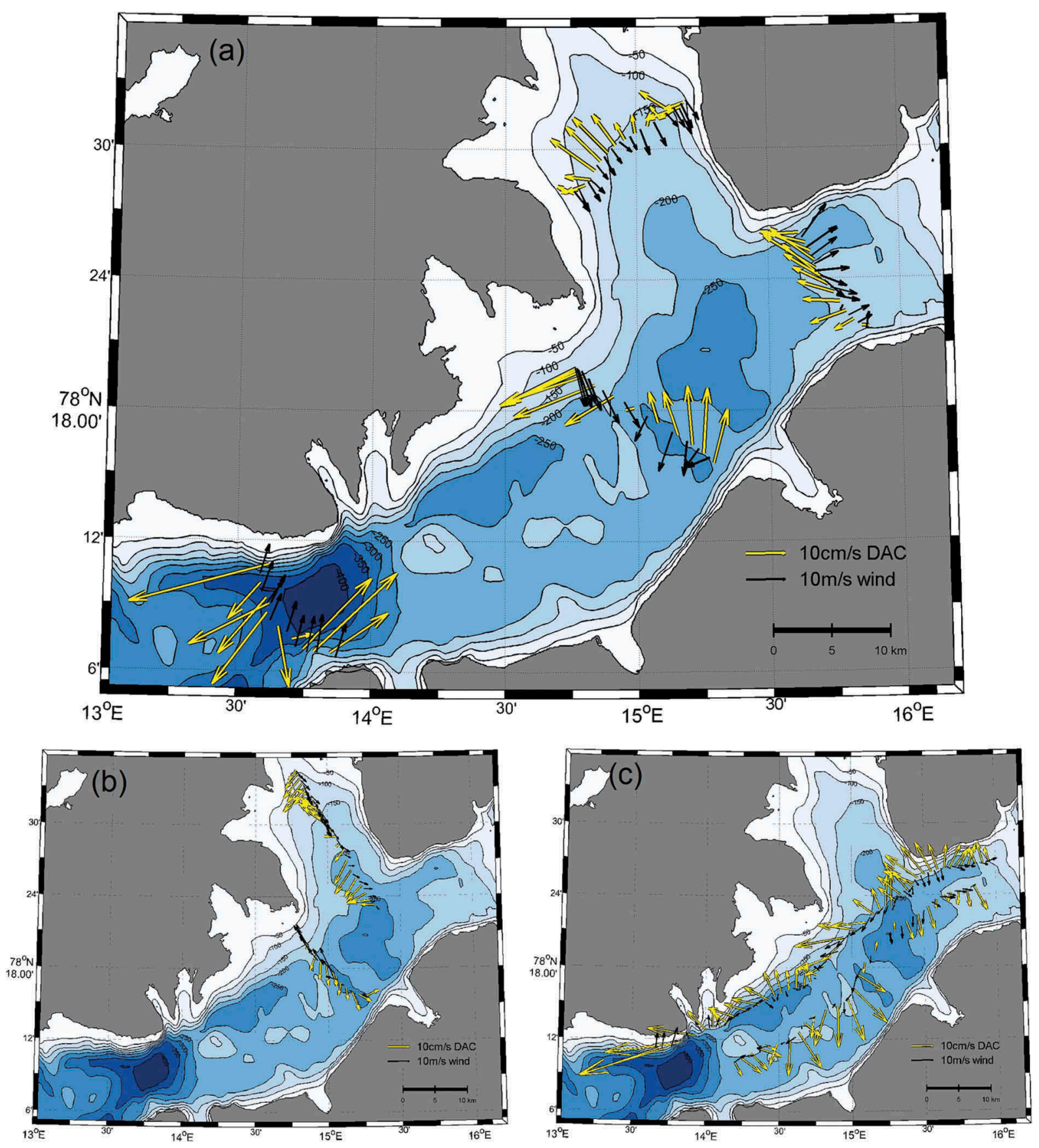

Figure 5. De-tided DACs, overlayed with corresponding $10 \mathrm{~m}$ wind velocity from the AROME-Arctic model, in (a) across-fjord sections in November 2014. (b) Sections 3 and 1b and (c) along-fjord Sections 5 and 7 are shown separately to avoid overlap. DACs vectors $(\mathrm{cm} / \mathrm{s})$ are shown in yellow while $10 \mathrm{~m}$ wind vectors $(\mathrm{m} / \mathrm{s})$ are shown in black.

forcing is changing significantly during the time period the transects are occupied, such as in Sections 5 and 7, which were taken over several days (Fig. 4).

The hydrography sections (Fig. 8) indicate that, during the period of study, Isfjorden may be treated as a two-layer, salinity-stratified system, with the pycnocline generally weaker at the mouth and stronger towards the head of Nordfjorden and Sassenfjorden. Much of the Isfjorden interior displayed a well mixed surface layer $\left(S_{A} \approx 34.8 \mathrm{~g} / \mathrm{kg}, 2<\Theta<3^{\circ} \mathrm{C}\right)$ around $100 \mathrm{~m}$ in depth, which falls under the category of IW $\left(\Theta>1{ }^{\circ} \mathrm{C}\right.$, $34.2<S_{A}<34.9 \mathrm{~g} / \mathrm{kg}$ [Svendsen et al. 2002]). Below this depth we see a deep layer consisting of both TAW $\left(1<\Theta<3^{\circ} \mathrm{C}, 34.9<S_{A}<35.1 \mathrm{~g} / \mathrm{kg}\right)$, a water mass generated by the mixing of AW and ArW (Svendsen et al. 2002), and AW. The range of temperature and salinity values detected by Freyja and Snotra are displayed in $\Theta-S_{A}$ space in Fig. 9. The lighter water masses within the fjord generally fall along a mixing line between IW and AW, with no Surface Water (SW, $1<\Theta<7^{\circ} \mathrm{C}, 30.1<S_{A}<34.2 \mathrm{~g} / \mathrm{kg}$ ) present, while AW is found in the deep layer. Temperature generally increases moving in-fjord from the mouth, with the coldest waters found in Section 6 and the 


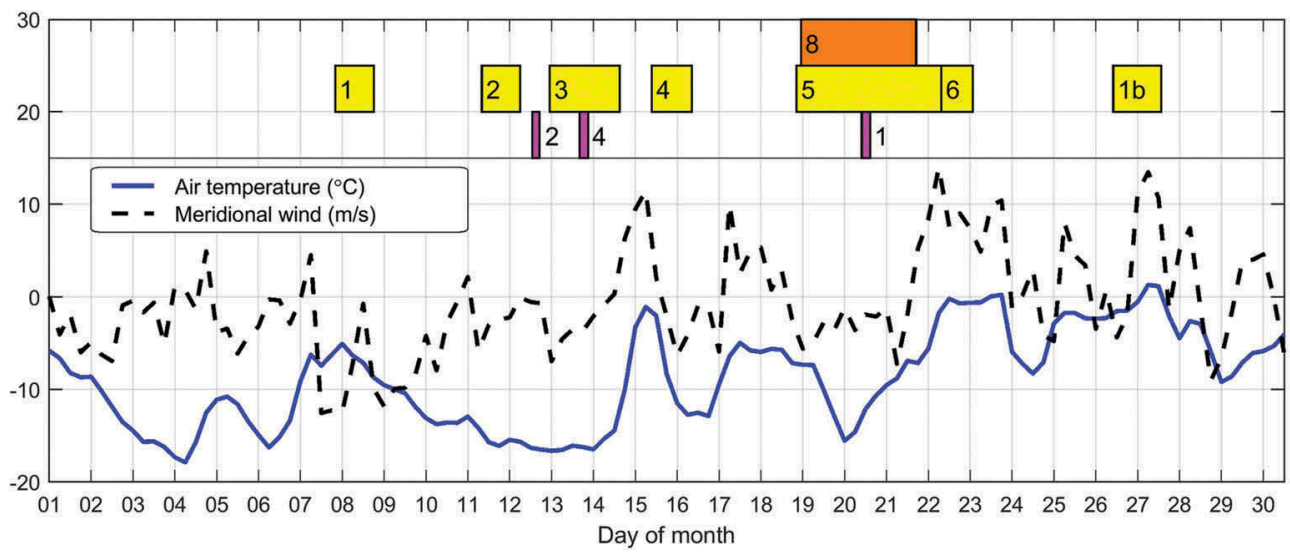

Figure 6. Air temperature at $2 \mathrm{~m}$ height in the Isfjorden region from the AROME-Arctic model (blue) along with the meridional wind component from Isfjord Radio weather station (dashed black). The bar along the top of the figure shows the time periods during which sections were being taken, with yellow and orange denoting Freyja and Snotra, and purple denoting CTD.
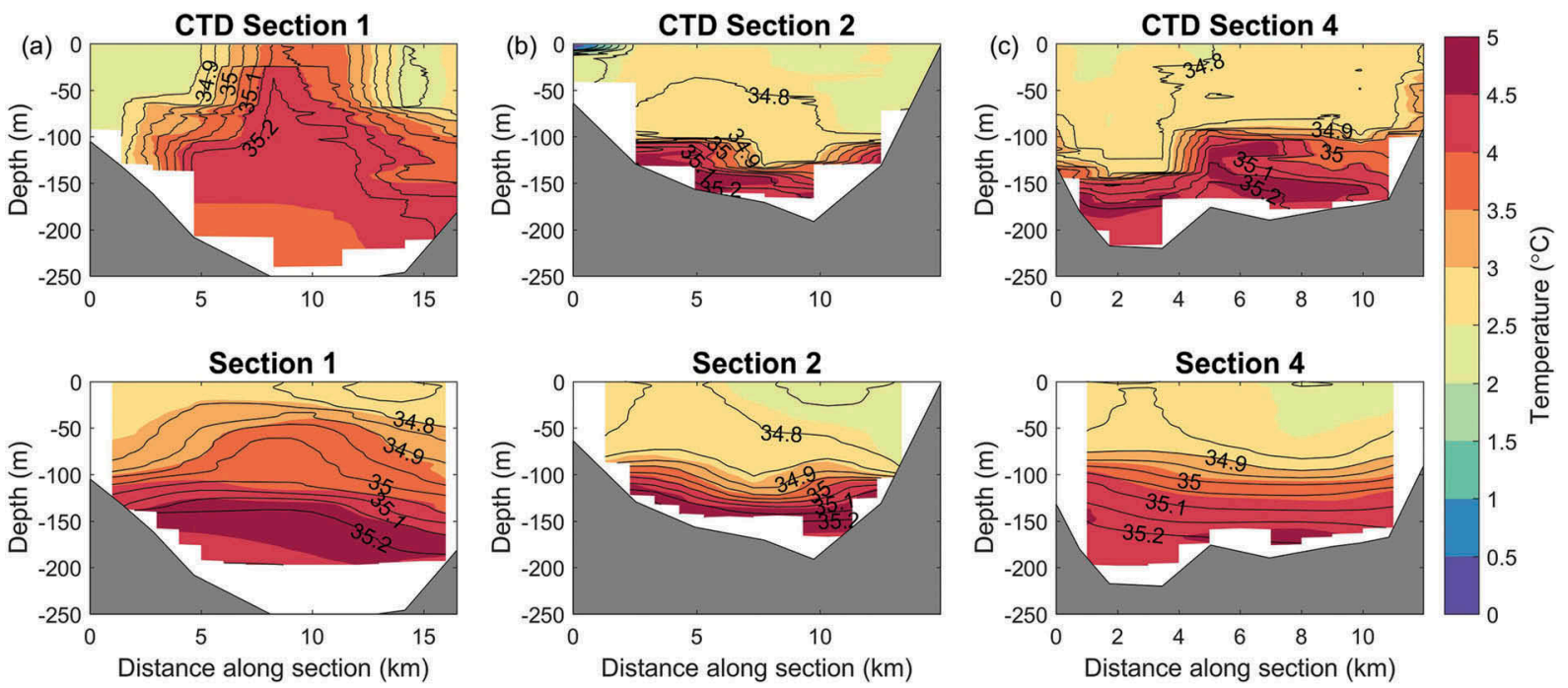

Figure 7. Conservative temperature $\left({ }^{\circ} \mathrm{C}\right)$ and absolute salinity $(\mathrm{g} / \mathrm{kg})$ from CTD for cross-fjord Sections 1,2 and 4 , with the corresponding glider section shown beneath for comparison. Sections 1 and 4 are viewed looking east, Section 2 is viewed looking north. Colour contours denote conservative temperature while solid black lines denote isohalines.

warmest waters found at the entrance to Nordfjorden (Section 3). Based on the available hydrographic data, we estimated $L_{R}$ to be $1.2 \mathrm{~km}$.

Sections 1, 5, 7 and CTD Section 1 all see the pycnocline tilt upwards in the Isfjorden mid-fjord region such that it almost reaches the surface, and taken together these sections describe a convex dome of warm and saline water residing there, centred around $5 \mathrm{~km}$ north-east of the intersection of Sections 1 and 7 (Fig. 2). Section 1b, taken six days later than CTD Section 1 at the same location, does not see this feature, the pycnocline having flattened out to a depth of around $100 \mathrm{~m}$. Sections 2 and 3 see pockets of $\mathrm{AW}$, some of the warmest observed in the region, reside near the bottom of Nordfjorden centred above the $100 \mathrm{~m}$ isobath on both sides and at the head of the fjord. Warm AW is also located at depth in Sassenfjorden, as seen in Sections 4 and 5. In
Sections 5 and 6, the deep layer in the fjord mouth was found to be colder than that in the fjord interior, and the stratification weaker. The freshest, coldest waters were found above $100 \mathrm{~m}$ at the north end of Nordfjorden (Section 3) and on the surface at the southern side of the Isfjorden mouth (Section 6).

The additional CTDs (Fig. 10) show that cold, saline ArW occupied the Isfjorden mid-fjord in April. The September data show a straight mixing line between these April conditions and AW, which suggests that AW was introduced into the fjord during the summer. There is also evidence of surface freshening over the summer due to the presence of very light and warm SW in September that has mixed with AW, creating a warm IW. By November the SW is no longer present, with the entire upper layer consisting of colder IW falling along a mixing line between AW and ArW. 

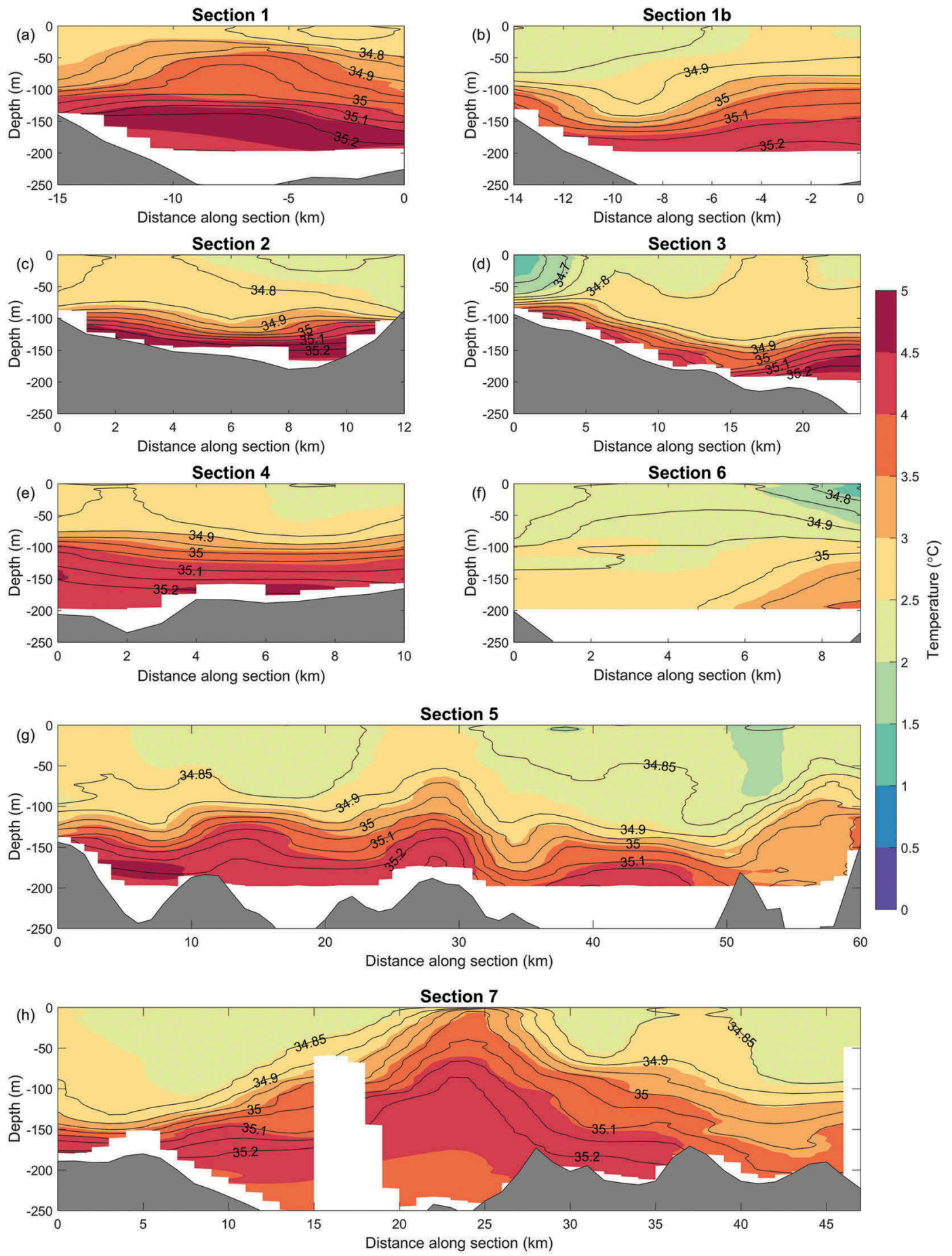

Figure 8. Conservative temperature $\left({ }^{\circ} \mathrm{C}\right)$ and absolute salinity $(\mathrm{g} / \mathrm{kg})$ from all glider sections. All sections are viewed looking east, other than Section 2 which is viewed looking north and Sections 5 and 7 which is viewed looking south. The negative scale on the horizontal axis for Section 1 is due to the fact that, unlike the others, this section was taken from right to left as viewed in the figure. Colour contours denote conservative temperature while solid black lines denote isohalines. In $(\mathrm{g})$, the fjord entrance is at $50 \mathrm{~km}$, with the fjord mouth beyond.

\section{Depth-averaged currents}

The de-tided DACs for all cross-sections are shown in Fig. 5. Speeds of up to $30 \mathrm{~cm} \mathrm{~s}^{-1}$ were observed across the fjord mouth (Section 6). In the fjord interior the DACs were considerably weaker, with the maximum value of $22 \mathrm{~cm} \mathrm{~s}^{-1}$ observed in Section 1 . Tidal currents seldom exceeded $2.5 \mathrm{~cm} \mathrm{~s}^{-1}$, and so had a significant influence only in regions where the
DACs were particularly weak. The DACs demonstrate across-fjord current variability in all cross-sections, though the velocity structure is highly variable between the sections. Section 1 and, in particular, Section 6 describe a strong inflow (outflow) near the southern (northern) shore of Isfjorden. Section 1b, which retraced Section 119 days later, did not exhibit this behaviour as strongly, displaying a generally southward flow, out of the fjord, with a small 

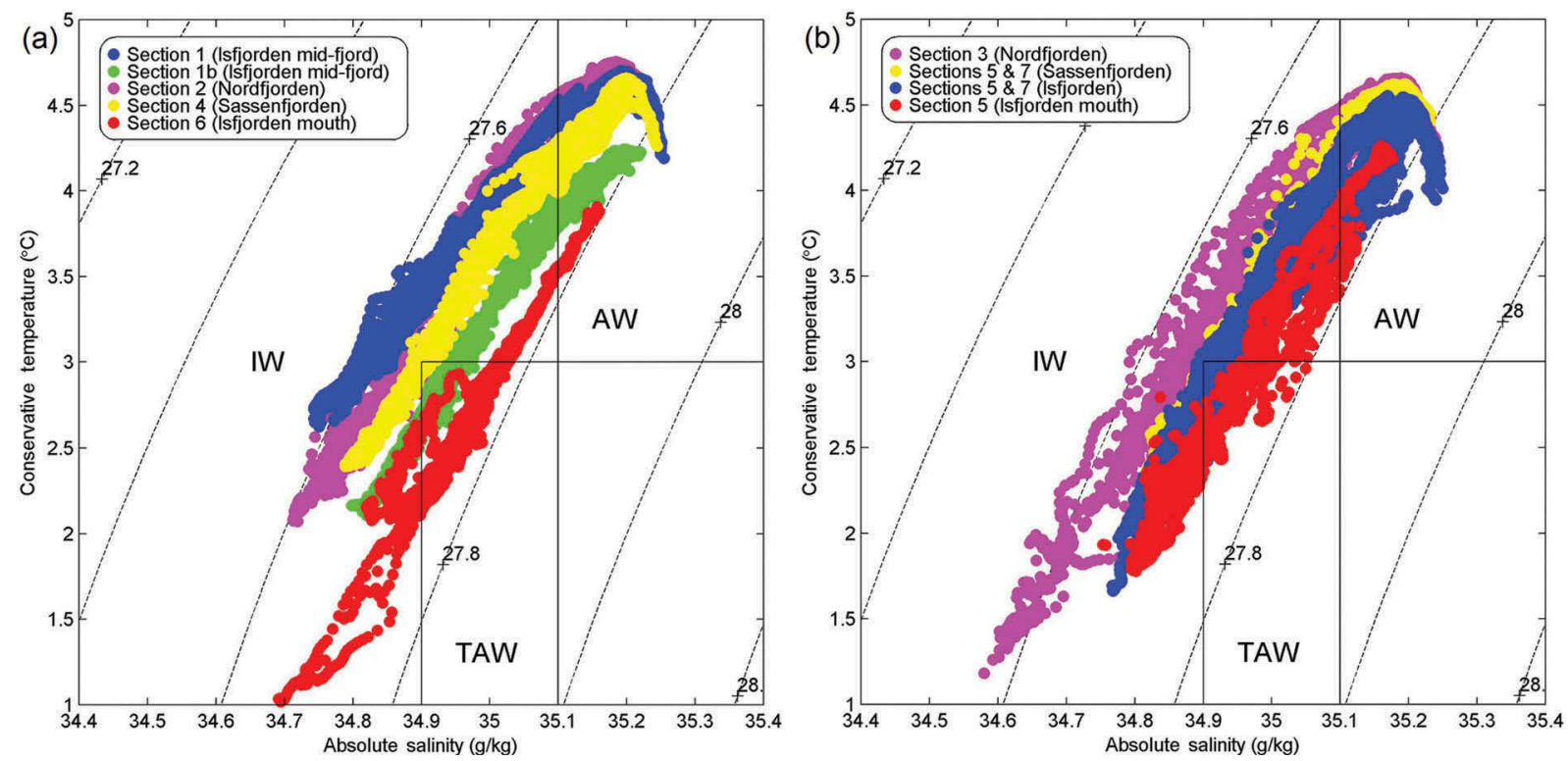

Figure 9. $\Theta-S_{A}$ diagram (a) cross-fjord sections of Isfjorden, Nordfjorden, Sassenfjorden and the Isfjorden mouth region and (b) along-fjord sections of Isfjorden and Nordfjorden. Data from the different sections are denoted by colour. Black boxes denotes AW, TAW and IW classifications.

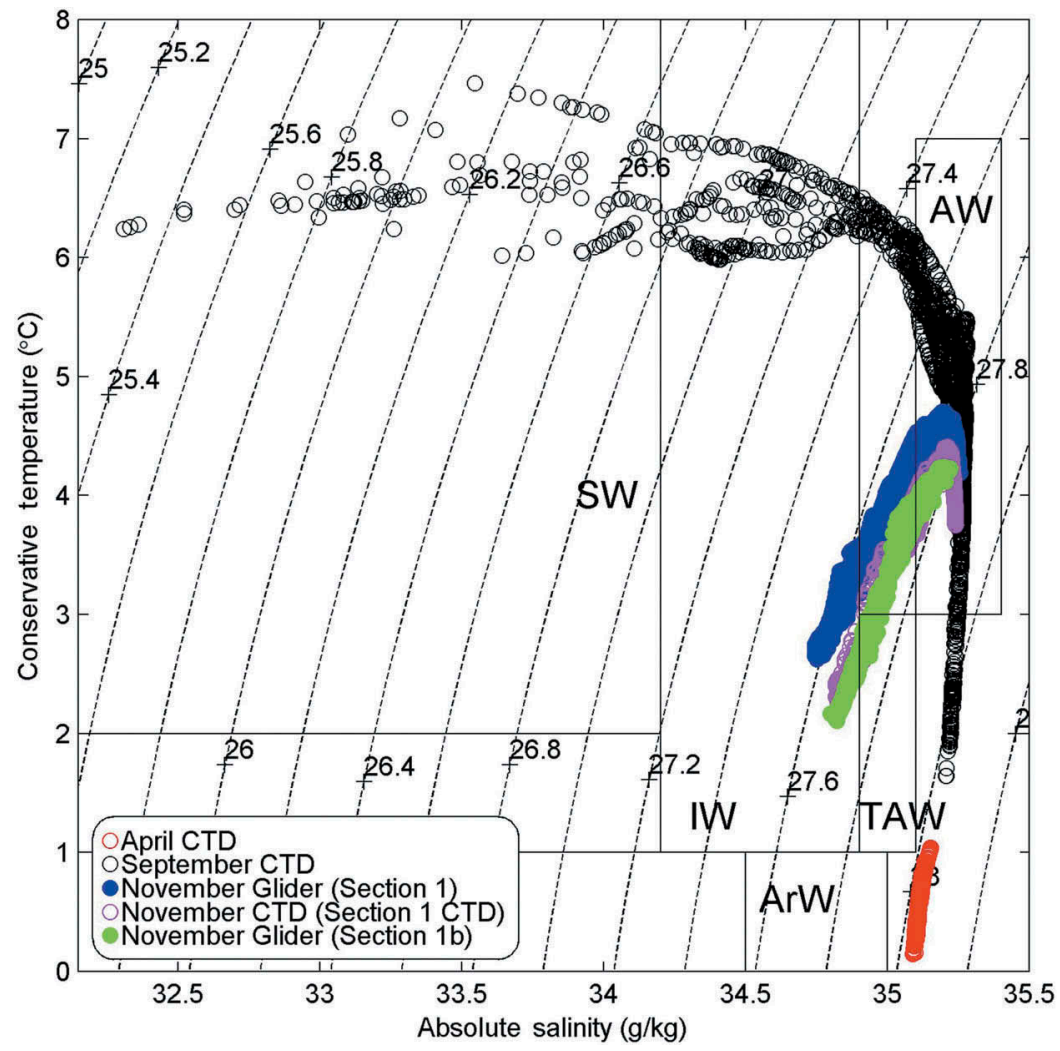

Figure 10. $\Theta-S_{A}$ diagram showing the evolution of central Isfjorden between April and November 2014, combining CTD and glider data.

region of moderate inflow (ca. $7 \mathrm{~cm} \mathrm{~s}^{-1}$ ) adjacent to the southern boundary. Section 4 , across the entrance to Sassenfjorden, describes a generally westward flow of about $10 \mathrm{~cm} \mathrm{~s}^{-1}$, with some variability in the current direction. Westward currents are observed both across the entrance and around the head of
Nordfjorden (Section 3), with northerly flow found on either side (Section 2). Section 5 describes an inflow on the right hand side of the Nordfjorden entrance, and generally shows an outflow along the northern bank of Isfjorden. Section 7 describes strong southerly flows along the centre-lines of both 

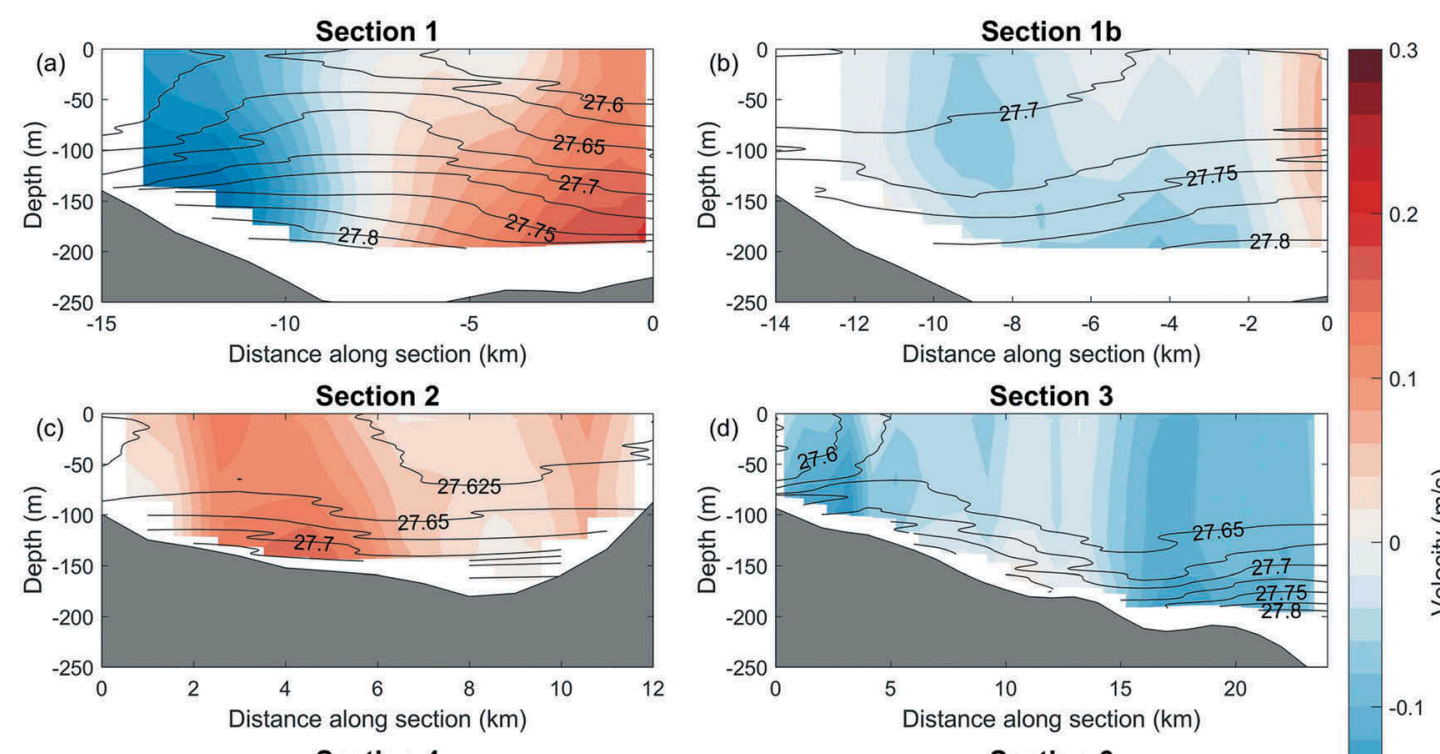

.1
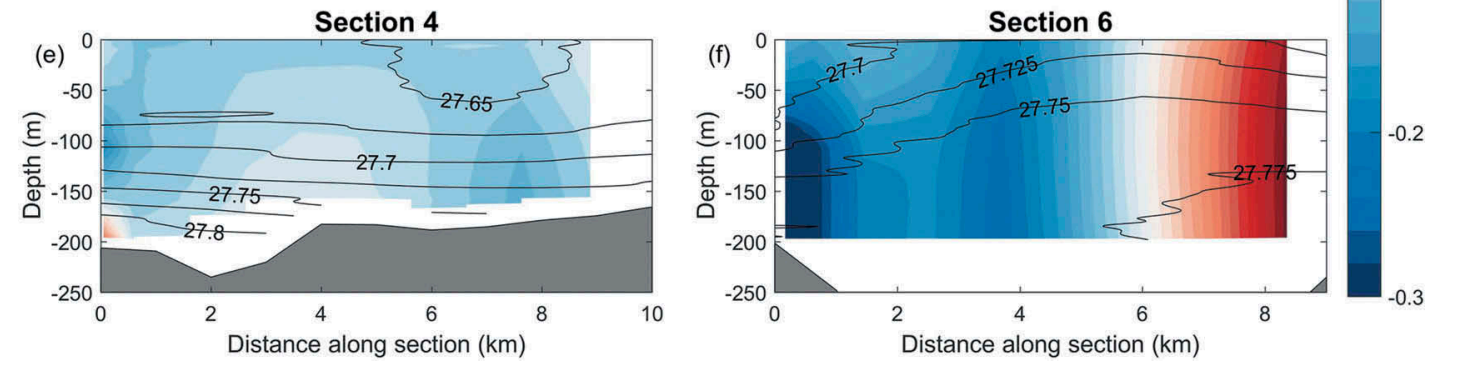

Figure 11. Absolute velocity fields, for cross-fjord Sections 1, 1b, 2, 4 and 6 and along-fjord Section 3. All sections are viewed looking east, other than Section 2, which is viewed looking north. Positive velocity here means a flow into the page. Solid black lines denote isopycnals of $\sigma_{\theta}$.

Table 4. Adjustment parameters used when referencing the absolute velocities using the DAC referencing method, $v_{\text {ref }}(x)$. The adjustment is different for each dive and therefore depends on the lateral position, $x$. Here the mean and maximum absolute values are given for each section. All values are given in $\mathrm{cm} \mathrm{s}^{-1}$.

\begin{tabular}{lcc}
\hline Section no. & $\overline{\left|v_{\text {ref }}(x)\right|}$ & $\max \left(\left|v_{\text {ref }}(x)\right|\right)$ \\
\hline 1 & 6.8 & 15.5 \\
2 & 6.1 & 13.6 \\
3 & 6.5 & 10.3 \\
4 & 6.0 & 8.0 \\
6 & 13.5 & 26.7 \\
$1 \mathrm{~b}$ & 2.8 & 6.2 \\
\hline
\end{tabular}

Sassenfjorden and Isfjorden, with some south-easterly currents to the south-west of the Isfjorden mid-fjord region.

\section{Absolute velocities}

The absolute velocity and potential density for fjord cross-sections are shown in Fig. 11. Although vertical shear was evident throughout the region, this was not always obvious in regions where the barotropic term from $v_{r e f}$ was dominant, such as in Sections 1 and 6. Section 1 sees fast inflows and outflows at all depths on the respective southern and northern sides, but also sees current speeds increasing with depth such that current cores are positioned at $200 \mathrm{~m}$. Section 6 has a similar horizontal structure but with stronger current speeds and a weaker baroclinic signal, with some vertical shear evident near the surface on the northern side. Sections $1 \mathrm{~b}$ and 4 describe a net outflow of Isfjorden and Sassenfjorden, respectively, with some cross-fjord variability but no distinct velocity pattern. Section 2 shows a northward flowing current core at depth towards the western side of Nordfjorden, while Section 3 describes westward flow at depth towards the north end of Nordfjorden, and a westward flow across the mouth of Nordfjorden at all depths. The mean adjustment parameter, $v_{r e f}$, for the entire study was $7.0 \mathrm{~cm} \mathrm{~s}^{-1}$, with a maximum value of $26.7 \mathrm{~cm} \mathrm{~s}^{-1}$ found in the Section 6 outflow region. The mean and maximum values for $v_{r e f}$ in each section are included in Table 4.

\section{Discussion}

\section{Circulation patterns in Isfjorden}

The DACs from Sections 1 and 6 display cross-fjord geostrophic circulation in central Isfjorden and in the mouth region, where the inflow takes place on the right-hand side and, correspondingly, outflow is observed on the left-hand side (looking into the fjord). This is consistent with the doming isopycnals in the mid-fjord region of Isfjorden which are 
symptomatic of a cyclonic eddy centred there. The DACs from the mid-fjord region in Sections 3 are also consistent with this cyclonic circulation structure. In the eastern and northern parts of Nordfjorden the DACs appear to follow a cyclonic flow pattern (Fig. 5), as would be expected in the geostrophic case. These results are in general agreement with other studies that report three-dimensional circulation in broad fjords in Svalbard (Ingvaldsen et al. 2001; Svendsen et al. 2002; Skogseth et al. 2005; Carroll et al. 2016; Sundfjord et al. 2017) and Greenland (Johnson et al. 2011; Inall et al. 2014; Carroll et al. 2017). The DACs from the end points of Sections 1 and 6 flow approximately tangent to isobaths, indicating that the geostrophic flow is guided by topography. Currents following contours deeper than about $200 \mathrm{~m}$ will circulate around central Isfjorden and have limited access to Nordfjorden and Sassenfjorden and, therefore, to glacier termini. This is consistent with the eddy pattern seen in the Section 1, 3 and 7 DACs, and the doming feature seen in Section 1, 7 and CTD Section 1 hydrography. In Section $1 \mathrm{~b}$ we see a southward flow in all but the southernmost DAC vectors. While qualitatively this fits the criterion of inflow (outflow) on the right (left), the strength of the inflow is much diminished in comparison to Section 1 and is not large enough to compensate for the outflow.

The absolute velocity field for Section 6 (Fig. 11f) is dominated by the barotropic signal, since the $z$-independent $v_{\text {ref }}$ was large. The dominance of the barotropic signal is likely due to the weak stratification here, hence we see velocities throughout the water column following the same isobaths, as is expected in a rotating barotropic fluid (Taylor 1917). Section 1 (Fig. 11a) sees a similar geostrophic circulation pattern reside in the fjord interior, inherited from the DACs, though the baroclinic term describes significant vertical shear and in general produces faster currents in the deeper layer than those at the surface. The fastest inflow in central Isfjorden, Section 1, is observed at around $200 \mathrm{~m}$, the maximum dive depth for Freyja.

The geostrophically balanced flow structure in the mouth and main body of Isfjorden (Sections 6 and 1) is not observed in the shallower side-fjords, Nordfjorden and Sassenfjorden (Sections 2 and 4). In the north-western part of Nordfjorden the DACs measured in Sections 2 and 3 seem to converge as the westward flow at the head of the fjord meets a northward flow near the western shore. If the circulation in Nordfjorden were geostrophically balanced, we would instead expect southward flowing currents on the western shore of the fjord, contrary to those seen in Section 2. The Section 3 temperature and absolute velocity fields (Figs. 8d, 11d) together describe a westward-travelling AW current core following the
$100 \mathrm{~m}$ isobath. However, on the western side of Section 2 (Fig. 11c), there is a northward flow of the entire water column, intensifying with depth, while on the eastern side we see northward flow which is strongest at the surface, both of which contradict this interpretation. The currents in Sassenfjorden, seen in Section 4, are largely directed out of the fjord without any counter flow, which suggests a net draining of the fjord. A small inflow can be seen in the southernmost DAC vector in Section 4, a similar structure to Section $1 \mathrm{~b}$, but it is not large enough to balance the outflow. The DACs in these regions may be more influenced by ageostrophic effects, giving a value for $v_{\text {ref }}$ that is not representative of the barotropic geostrophic signal, therefore obscuring the mean velocity structure in Nordfjorden and Sassenfjorden. It is likely, however, that the barotropic currents observed in the main body of Isfjorden are steered by contours deeper than the side fjords, and hence have a limited influence on these regions.

We anticipated that the time spent by the glider on the surface before and after dives would skew the DAC towards the surface velocity, which is heavily influenced by wind activity. Counter-intuitively, the opposite appears to be true, particularly in Sections 2 and 4, where the DAC vectors lie opposed to the $10 \mathrm{~m}$ wind velocity vectors. Possible causes include residual tidal signal, supposing tides are stronger in Nordfjorden and Sassenfjorden than captured by the tidal model, and barotropic seiching motions. However, Section 4 was around 23 hours in duration, so tides cannot account for the sustained out-fjord velocities found there. The barotropic seiching period, given by Merian's formula $T=4 L /^{\sqrt{g H}}$ (Von der Mühll 1886), is on the order of 1 hour in Nordfjorden and Sassenfjorden, given a fjord length $L$ of $25 \mathrm{~km}$ and an average depth $H$ of $150 \mathrm{~m}$, so again this does not explain the observed DAC structure. We speculate that the small inflows seen in the southernmost DACs of Sections 4 and $1 \mathrm{~b}$ may represent intensified inflows residing above the steep, narrow slope, which were not fully captured by the glider due to their small spatial extent and proximity to the coast. A similar phenomenon may explain the seemingly unbalanced circulation in Section 2.

In cases where the DACs have no clear geostrophic influence we appeal to the hydrography, which is less variable over short timescales, to give a better indication of the background circulation pattern. Section 2 hydrography (Fig. 8c) points towards a geostrophic current at depth, where we see a downward sloping of the isopycnals towards the boundaries and two AW cores, one on either side of the fjord bottom. This type of structure is not seen in the density distributions of either Sections 4 (Sassenfjorden) or $1 \mathrm{~b}$, each of which is consistent with a lateral overturning circulation. 


\section{Heat distribution and transport}

From the $\Theta-S_{A}$ diagram (Fig. 9), we see that temperature increases with distance into the fjord, with the warmest waters found in Nordfjorden and the coolest found at the fjord mouth, showing that $\mathrm{AW}$ is able to penetrate the upper reaches of the Isfjorden system. Relatively little AW was found in Section 6, however the water depth at the Isfjorden mouth exceeds $400 \mathrm{~m}$, so it is possible that $\mathrm{AW}$ was resident there at a greater depth than the $200 \mathrm{~m}$ rated glider was able to observe. The differences between the water column in the fjord and in the mouth are highlighted at the western end of Section 5 (Fig. $8 \mathrm{~g}$ ), where a vertical temperature front is present $50 \mathrm{~km}$ along the section between the IW in the fjord interior and SPC origin water found in the mouth. The absence of these mouth-resident water masses throughout most of the fjord interior suggests that the front is caused by a branch of the SPC circulating across the fjord entrance. This is consistent with the cold inflow seen at the southern side of Section 6 (Fig. 8f). A downwards slope towards the fjord is observed in the isohalines (which are a good proxy for the isopycnals, not shown) outside the fjord (beyond $50 \mathrm{~km}$ in Fig. 8g), restricting AW or TAW exchange in the lower layer as explained in Nilsen et al. (2008). This coastal down welling is due to the strong southerly winds recorded at Isfjord Radio at this time. The density front associated with the negative (eastwards) tilt of the pycnocline, together with increased northward barotropic flow due to the positive sea surface tilt, indicates a geostrophic control mechanism that acted to shut off the fjord from the shelf. Although geostrophic control was in place during the occupation of Section 5, the introduction of AW into the fjord system between April and September (Fig. 10) implies that deep layer exchange flows are sometimes permitted.

The absolute velocity and hydrography fields from Section 6 were combined to give a positive heat flux of $0.13 \mathrm{TW}$, indicating that heat is delivered up-fjord by the geostrophically balanced shelf currents circulating in the mouth. This seems to contradict the cooling trend seen in the time evolution of the fjord over November (Fig. 9a). However, because of the geostrophic control observed in Section 5, where the AW outside the fjord is cut off from that inside by coastal down welling in the mouth, it cannot be assumed that this heat was delivered to the fjord interior. We may have witnessed an anomalously warm region of the STC on the southern side of Section 6, destined to simply recirculate in the fjord mouth before continuing northwards on the shelf. Also, as previously noted, the water depth at Section 6 is considerably deeper than the maximum glider dive depth, giving rise to large uncertainties in the calculated heat flux value. The result is valuable, however, for estimating the potential magnitude of heat delivery when geostrophic control is not in place. Results from synoptic sections of broad fjords in Greenland give a heat flux of the same order, with Inall et al. (2014) reporting 0.26 TW in Kangerdlugssuaq Fjord, Rignot et al. (2010) finding 0.16 TW in Tor Fjord and Johnson et al. (2011) finding a flux of 0.31 TW in Petermann Fjord. Sermilik Fjord is similarly sized though narrower than $L_{R}$ at the mouth, and the circulation there is therefore restricted to a simple two-dimensional overturning structure. Synoptic measurement of the temperature and background circulation have given a heat flux of only 0.029 TW (Sutherland \& Straneo 2012) in Sermilik, although this value may be considerably higher if one assumes a non-zero net contribution over time from the first baroclinic mode (Sutherland et al. 2014). The order of magnitude difference highlights the capacity for broad fjords, such as Isfjorden, to accommodate intense exchange flows which rapidly redistribute heat.

\section{Atmospheric controls}

The strong north-easterly wind event at Isfjorden Radio, starting on 7 November (Fig. 4), is indicative of a northerly shelf wind which is directed out-fjord through topographic steering. Strong winds are found at all weather stations during this event, and in each case they are locally oriented down-fjord. Likewise, when strong southerly shelf winds are detected at Isfjorden Radio, such as on the 22nd and 23rd, an up-fjord wind is detected at all other stations. It is worth noting this correlation between the along-shelf wind direction and the direction of the wind stress acting locally on the fjord as we see evidence for local wind activity driving two-layer, cross-fjord circulation patterns via surface Ekman transport. The upwelling on the northern side of Sassenfjorden (Fig. 8e) indicates a cross-fjord velocity component in the Ekman layer due to the strong up-fjord winds detected on the 15th (Fig. 4). Similarly, the crossfjord tilt in the pycnocline in Section $1 \mathrm{~b}$ may be a residual effect of the moderate out-fjord wind on the 24th and 25th at Bohemanesset (Fig. 4c). This type of response to the action of along-fjord winds is a feature specific to broad fjords. The localized topographic steering of winds may therefore allow us to indirectly associate lateral redistribution of heat and salt with large-scale weather changes.

The change in $\Theta-S_{A}$ properties at Section 1 between September and early November (Fig. 10) indicates two scenarios; either that the IW inside the fjord was cooled and then mixed with AW, or that the fjord was subject to an influx of ArW (or 
ArW influenced IW). The prevailing north-easterlies at Isfjorden Radio during the beginning of November (including the particularly strong north-easterlies between 7 and 9 November, during which Section 1 was taken) would have acted to lift the pycnocline in the fjord mouth. Given a good agreement between the density structure in the fjord mouth and that in the fjord, this would allow a geostrophically balanced, largely barotropic exchange flow to advect deep-layer AW from the shelf into the fjord interior. The $\Theta-S_{A}$ signature within Isfjorden in November closely matches that on the shelf (Fig. 9a), therefore the transformation in water properties between the September CTD section and Section 1 (Fig. 10) may be attributable, at least in part, to an intrusion of shelf-resident water at this time. This is reflected in the exchange flow seen in the Section 1 absolute velocity field (Fig. 11a). Furthermore, because of the doming feature in the Section 1 hydrographic fields (Fig. 8a), currents intensified with depth because of thermal wind shear so that the strongest exchange took place in the deep layer. Sections 2, 3 and 4, taken after the northerly wind event had ceased, show that the $\mathrm{AW}$ in the deep layer was also able to reach Nordfjorden and Sassenfjorden.

The temporal change in hydrography and velocity structure in central Isfjorden between Sections 1, CTD 1 and $1 \mathrm{~b}$ may be linked to both atmospheric heat exchange and fjord/shelf exchange flows, both of which may be attributed to the shift in on-shelf weather patterns between mid and late November. Meridional wind direction is also closely linked to air temperature above Isfjorden (Fig. 6) because southerly winds bring warm air into the region from the tropics while northerlies transport cold air from the Arctic. Section 1 was taken during the period when northerly winds were dominant, CTD Section 1 was taken during the transition in prevailing wind direction, while Section $1 \mathrm{~b}$ was taken when the prevailing winds were from the south. In CTD Section 1, the water temperature was lower than in Section 1 while the gradient in $\Theta-S_{A}$ space remained the same, consistent with heat loss to the atmosphere. Although meridional wind stress on the shelf was weak (Fig. 6), the doming feature in central Isfjorden had become more pronounced, bringing AW into direct contact with the atmosphere, and indicating that a cyclonic eddy structure persisted there even after the strong northerly on-shelf winds had relaxed. We therefore suggest that, during this time, the deep-layer circulation in central Isfjorden was dynamically independent from the strongly barotropic circulation in the fjord mouth due to a reinstated geostrophic control mechanism (Fig. 12), and that the cooling observed there was due to strong atmospheric heat loss enhanced by the doming structure. The air was colder $\left(\mathrm{ca} .-10^{\circ} \mathrm{C}\right)$ than at any other time in the second half of November, further evidence of strong atmospheric heat loss. In Section $1 \mathrm{~b}$ the deep layer had cooled further still while the central doming was no longer apparent, so that the deep layer was well insulated from the atmosphere. The air temperature was the warmest seen in November (ca. $0^{\circ} \mathrm{C}$ ), weakening the temperature gradient at the airsea interface and therefore diminishing atmospheric heat loss. Geostrophic control was in place on the 22nd in the westernmost part of Section 5, and we presume that this remained true during Section $1 b$ as strong southerlies prevailed on shelf throughout this time. The $\Theta-S_{A}$ diagram for November (Fig. 9a)

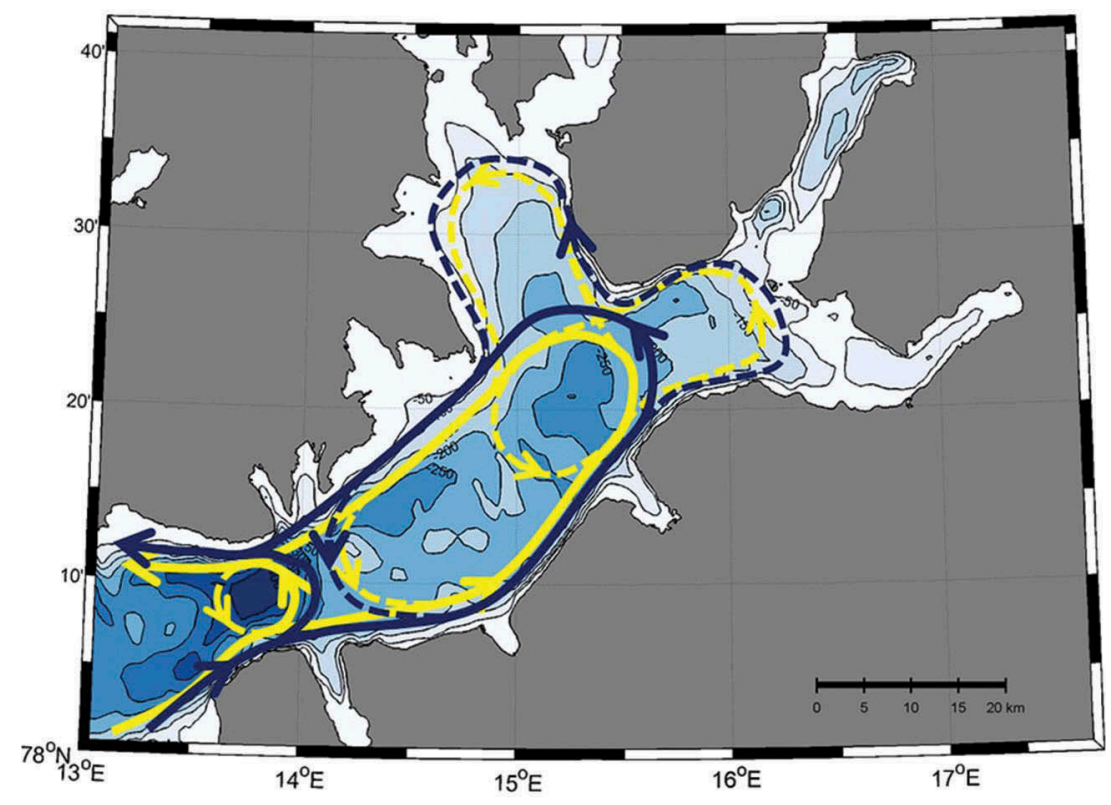

Figure 12. Schematic of the circulation and shelf exchange scheme in Isfjorden. The lower layer circulation is denoted by yellow arrows, the upper layer by blue. Dashed lines indicate proposed pathways which were not observed directly. 
confirms this, with the constant gradient indicating a continuation of the cooling trend between the 7th and the 20th, with no evidence of further deep-layer exchange. However, the $\Theta-S_{A}$ structure in the mouth (Fig. 9a, Section 6) was similar, though denser, to that of the fjord interior, and the introduction of this mouth-resident water into the fjord interior would also lead to water masses consistent with those seen in Section 1b. We therefore acknowledge that while air-sea heat flux was weak on account of increased air temperatures, we may have witnessed additional cooling through upper-layer exchange during the period of strong southerly winds in late November.

\section{Evaluation of glider performance}

The glider data provided a description of the circulation within Isfjorden in greater detail than previously available. The spatial resolution of the temperature and salinity data was generally higher than that from the ship-based CTD sections (Table 2). A crucial advantage is the ability to obtain current measurements with equally high spatial resolution, giving a spatial aspect to the circulation not offered by mooring-mounted current meters. The ability to combine DAC and potential density data to yield a two-dimensional, absolute velocity field allowed us to generate a richer picture of the circulation structure than offered by moorings.

Several key issues need to be considered when assessing the performance on the Slocum gliders in this environment. A fundamental problem with any point measurement that is used to cover an area spatially, like a glider, is that between the measurements there is a time lag. If the glider progresses with a horizontal speed of $30 \mathrm{~cm} \mathrm{~s}^{-1}$, it will take around 10 hours to cover a $10 \mathrm{~km}$ long section, compared to around 2 hours for a CTD transect. Over 10 hours the wind and tidal currents will be subject to change, and so spatial and temporal variability are inseparable. This will likely affect the upper layer hydrography and DAC measurement in particular, as wind forcing may cause these to change over shorter time scales than the conditions at depth. This intrinsic uncertainty could explain the observed pile-up of water in north-west Nordfjorden. As these two convergent flows were measured at different times, it is probable that they are due to temporal fluctuations in the mean flow and do not together represent a steady state. Encouragingly, comparison of Sections 2 and 4 with their CTD section counterparts (Fig. 7), each taken within two days of the relevant glider section, shows no drastic change in the deep layer hydrographic structure, suggesting that the glider hydrography data may be considered synoptic for shorter cross-fjord sections.
The gliders' DAC measurement relies on a deadreckoning procedure which may be inaccurate in regions of high vertical or horizontal shear. Also, the DACs are unable to distinguish between geostrophic and ageostrophic velocity components, such as tides, boundary layer flows and barotropic seiching motions. Modelled tides were subtracted from the observed currents in an effort to counter the effect of high frequency tidal signal. However, the model resolution of $5 \mathrm{~km}$ may have failed to capture some of the finer tidal velocity structure in this restricted region with steep topography, leading to a residual ageostrophic tidal signal in the DAC data. The uncertainty in DAC measurement due to wind-driven surface drift, during the time interval between the glider surfacing and picking up position data via GPS, is not known. Although the positions used for the DAC calculation are based on GPS fixes generally taken immediately before diving and immediately after surfacing, the time taken to establish a GPS fix after surfacing is subject to variability. One potential means of overcoming this effect in future would be to use data from the gliders drift times between dives to estimate the effect of wind forcing on the subsequent dive. However, this would rely on a new set of assumptions over GPS lag times and the steadiness of wind forcing.

The glider coverage was not as extensive as that offered by ship-based CTD sections, which is easily seen by comparing Section 1, 2 and 4 to their corresponding CTD sections (Fig. 7). Firstly, the fact Freyja was rated to only $200 \mathrm{~m}$ meant that the deepest waters in the region could not be surveyed in Sections 1, 6 and 7. This is seen in Fig. 8g, h, where the $1000 \mathrm{~m}$ glider Snotra was able to follow the bathymetry more closely Freyja. Comprehensive depth coverage of Section 6 would allow for a more accurate calculation of the heat flux through the fjord mouth. Secondly, the gliders were not navigated as close to shore as the ship was, so that glider sections were in general shorter than the CTD sections. When studying regions with intensified coastal currents this issue is particularly problematic, as these currents may have small spatial extents but make large contributions towards volume transport. This type of issue may have arisen in Sections $1 \mathrm{~b}$ and 4 , where the inflow did not compensate the outflow, and the glider failed to cover the most southerly part of the sections. In each case, in the moderate inflow seen in the southernmost DAC vector we may have glimpsed the fringes of a localized slope current, having failed to navigate the glider through its core. Gliders are generally flown onshelf or in the open ocean, so in this study extra caution was required by the pilot not to ground the glider in this confined area with steep topography. If glider missions are to become a conventional survey technique for fjords then it is likely that the spatial coverage they offer will increase as pilots and researchers gain 
experience and confidence in these environments. The feasibility for glider-based measurements is, at present, substantially reduced in fjord systems containing substantial sea-ice/iceberg cover. Gliders are starting to be used in regions of non-zero sea ice concentration (Lee \& Thomson 2017) and near icebergs (Zhou et al. 2015), indicating that these obstacles can be overcome in a fjordic setting.

\section{Conclusions}

The glider mission in Svalbard provided a new insight into the circulation patterns in Isfjorden, as well as on the operation of gliders in the polar night and in shallow fjordic systems. No previous studies of the circulation inside fjords have been carried out using gliders, nor have gliders been operated at such high northern latitudes during the polar night. The complex topography of fjords, varying sharply in depth and relatively small in area compared to the continental shelf and the open ocean, presents a new frontier for glider technology, but, based on this experiment, gliders can be successfully operated in certain fjordic environments. The spatial resolution was excellent, providing both cross- and along-fjord sections of DAC, while providing CTD data which was subsequently used to calculate geostrophic currents and to study the hydrography. The horizontally sheared flow regimes observed in the DACs in central Isfjorden and at the mouth indicate that geostrophy has a major influence on the circulation in these areas. This type of circulation has the capacity to rapidly deliver heat to broad fjords, and here we calculated a positive heat flux of $0.13 \mathrm{TW}$ at the mouth. Large-scale weather systems on the shelf have been seen to influence the water-mass structure and circulation scheme within Isfjorden through both local and non-local effects.

The DAC measurements were limited by the uncertainties associated with wind and tides, as well as the entanglement of spatial and temporal change. The gliders' spatial coverage of fjordic sections, in both the vertical and horizontal, can be improved upon in future though the use of a deeper diving instrument and bolder piloting, as the first survey of its kind, the results shown here would benefit from comparison with future glider missions in the region. It would be instructive as to which of the features observed here are transient fluctuations, and which are symptomatic of the long-term mean circulation in the region. Furthermore, repeated monitoring such as this would help to identify any temporal trends in airsea interaction, which is crucial for understanding the recent decrease in winter sea ice extent in Svalbard's fjords.

\section{Acknowledgements}

We appreciated the glider piloting and systems support from Erik M. Bruvik, Karsten Kvalsund and Idar Hessevik. Students Elisa Lindgren and Torbjørn Taskjelle contributed towards the initial field report from which this work was borne. Please contact the corresponding contact author to obtain the data described in this paper.

\section{Disclosure statement}

No potential conflict of interest was reported by the authors.

\section{Funding}

Gliders were provided by the Norwegian Atlantic Current Observatory and the Research Council of Norway (grant no. 197316). NJF was supported by a Natural Environment Research Council PhD studentship [project no. N0406]. Funding for RS and FN came from Remote Sensing of Ocean Circulation and Environmental Mass Changes, a Research Council of Norway project (no. 222696/F50). MEI was supported by Fluxes Across Sloping Topography of the North East Atlantic, a Natural Environment Research Council project (no. N0066).

\section{ORCID}

Neil J. Fraser (D) http://orcid.org/0000-0002-2171-9060 Ragnheid Skogseth (1) http://orcid.org/0000-0003-0210-4981 Frank Nilsen (i) http://orcid.org/0000-0003-4792-7172

Mark E. Inall (D) http://orcid.org/0000-0002-1624-4275

\section{References}

Bachmayer R., de Young B. \& Holland D. 2007. Working towards ice profiling using underwater gliders: operational experience in western Greenland. Presented at the 15th Symposium on Unmanned Untethered Submersible Technology (UUST07), 19-22 August, Durham, NH.

Barnes S.L. 1994. Applications of the Barnes Objective Analysis Scheme. Part II: improving derivative estimates. Journal of Atmospheric and Oceanic Technology 11, 1449-1458.

Carroll D., Sutherland D.A., Hudson B., Moon T., Catania G.A., Shroyer E.L., Nash J.D., Bartholomaus T.C., Felikson D., Stearns L.A., Noël B.P.Y. \& van den Broeke M.R. 2016. The impact of glacier geometry on meltwater plume structure and submarine melt in Greenland fjords. Geophysical Research Letters 43, 9739-9748.

Carroll D., Sutherland D.A., Shroyer E.L., Nash J.D., Catania G.A. \& Stearns L.A. 2017. Subglacial dischargedriven renewal of tidewater glacier fjords. Journal of Geophysical Research-Oceans 122, 6611-6629.

Cottier F.R., Nilsen F., Enall M.E., Gerland S., Tverberg V. \& Svendsen H. 2007. Wintertime warming of an Arctic shelf in response to large-scale atmospheric circulation. Geophysical Research Letters 34, doi: 10.1029/2007GL029948.

Cottier F.R., Nilsen F., Skogseth R., Tverberg V., Skardhamar J. \& Svendsen H. 2010. Arctic fjords: a review of the oceanographic environment and dominant physical processes. In J.A. Howe et al. (eds.): Fjord systems and archives. Geological Society Special publication 344. Pp. 35-50. London: Geological Society. 
Cottier F.R., Tverberg V., Inall M.E., Svendsen H., Nilsen F. \& Griffiths C. 2005. Water mass modification in an Arctic fjord through cross-shelf exchange: the seasonal hydrography of Kongsfjorden, Svalbard. Journal of Geophysical Research-Oceans 110, C12005, doi: 10.1029/2004JC002757.

Garau B., Ruiz S., Zhang W.G., Pascual A., Heslop E., Kerfoot J. \& Tintoré J. 2011. Thermal lag correction on Slocum CTD glider data. Journal of Atmospheric and Oceanic Technology 28, 1065-1071.

Inall M.E. \& Gillibrand P.A. 2010. The physics of midlatitude fjords: a review. In J.A. Howe et al. (eds.): Fjord systems and archives. Geological Society Special publication 344. Pp. 17-33. London: Geological Society.

Inall M.E., Murray T., Cottier F.R., Scharrer K., Boyd T. \& Heywood K.J. 2014. Oceanic heat delivery to the southeast Greenland ice sheet. Journal of Geophysical Research-Oceans 119, 631-645.

Inall M.E., Nilsen F., Cottier F.R. \& Daae R. 2015. Shelf/fjord exchange driven by coastal-trapped waves in the Arctic. Journal of Geophysical Research-Oceans 120, 8283-8303.

Ingvaldsen R., Reitan M.B., Svendsen H. \& Asplin L. 2001. The upper layer circulation of Kongsfjorden and Krossfjorden-a complex fjord system on the west coast of Spitsbergen. Memoirs of National Institute of Polar Research Special Issue 54, 393-407.

Janzen C.D., Simpson J.H., Inall M.E. \& Cottier F. 2005. Across-sill circulation near a tidal mixing front in a broad fjord. Continental Shelf Research 25, 1805-1824.

Johnson H.L., Münchow A., Falkner K.K. \& Melling H. 2011. Ocean circulation and properties in Petermann Fjord, Greenland. Journal of Geophysical ResearchOceans 116, doi: 10.1029/2010JC006519.

Klinck J.M., O’Brien J.J. \& Svendsen H. 1981. A simple model of fjord and coastal circulation interaction. Journal of Physical Oceanography 11, 1612-1626.

Lee C.M. \& Thomson J. 2017. An autonomous approach to observing the seasonal ice zone in the western Arctic. Oceanography 30, 56-68.

Luckman A., Benn D.I., Cottier F., Bevan S., Nilsen F. \& Inall M. 2015. Calving rates at tidewater glaciers vary strongly with ocean temperature. Nature Communications 6, article no. 8566, doi: 10.1038/ncomms9566.

McDougall T.J. \& Barker P. 2011. Getting started with TEOS-10 and the Gibbs Seawater (GSW) oceanographic toolbox. Scor/Iapso Wg127. Scientific Committee on Scientific Research/International Association for the Physical Sciences of the Oceans.

Merckelbach L.M., Briggs R.D., Smeed D.A. \& Griffiths G. 2008. Current measurements from autonomous underwater gliders. In: Proceedings of the IEEE/OES 9th working conference on current measurement technology. Pp. 61-67. Institute of Electrical and Electronics Engineers.

Muckenhuber S., Nilsen F., Korosov A. \& Sandven S. 2016. Sea ice cover in Isfjorden and Hornsund, Svalbard (2000-2014) from remote sensing data. The Cryosphere 10, 149-158.

Murray T., Scharrer K., James T.D., Dye S.R., Hanna E., Booth A.D., Selmes N., Luckman A., Hughes A.L.C., Cook S. \& Huybrechts P. 2010. Ocean regulation hypothesis for glacier dynamics in southeast Greenland and implications for ice sheet mass changes. Journal of Geophysical Research-Earth Surface 115, F03026, doi: 10.1029/2009JF001522.

Nilsen F., Cottier F.R., Skogseth R. \& Mattsson S. 2008. Fjordshelf exchanges controlled by ice and brine production: the interannual variation of Atlantic Water in Isfjorden, Svalbard. Continental Shelf Research 28, 1838-1853.
Nilsen F., Skogseth R., Vaardal-Lunde J. \& Inall M.E. 2016. A simple shelf circulation model: intrusion of Atlantic Water on the West Spitsbergen Shelf. Journal of Physical Oceanography 46, 1209-1230.

Nuth C., Kohler J., König M., Von Deschwanden A., Hagen J.O., Kääb A., Moholdt G. \& Pettersson R. 2013. Decadal changes from a multi-temporal glacier inventory of Svalbard. The Cryosphere 7, 1603-1621.

Nuth C., Moholdt G., Kohler J., Hagen J.O. \& Kääb A. 2010. Svalbard glacier elevation changes and contribution to sea level rise. Journal of Geophysical Research-Earth Surface 115, F01008, doi: 10.1029/ 2008JF001223.

Onarheim I.H., Smedsrud L.H., Ingvaldsen R. \& Nilsen F. 2014. Loss of sea ice during winter north of Svalbard. Tellus A: Dynamic Meteorology and Oceanography 66, article no. 23933, doi: 10.3402/tellusa.v66.23933.

Padman L. 2004. A barotropic inverse tidal model for the Arctic Ocean. Geophysical Research Letters 31, 2-5.

Pavlov A.K., Tverberg V., Ivanov B.V., Nilsen F., FalkPetersen S. \& Granskog M.A. 2013. Warming of Atlantic Water in two west Spitsbergen fjords over the last century (1912-2009). Polar Research 32, article no. 11206, doi: 10.3402/polar.v32i0.11206.

Pawlowicz R., Beardsley B. \& Lentz S. 2002. Classical tidal harmonic analysis including error estimates in MATLAB using T-TIDE. Computers and Geosciences 28, 929-937.

Rignot E., Koppes M. \& Velicogna I. 2010. Rapid submarine melting of the calving faces of west Greenland glaciers. Nature Geoscience 3, 187-191.

Schofield O., Kohut J., Aragon D., Creed L., Graver J., Haldeman C., Kerfoot J., Roarty H., Jones C., Webb D. \& Glenn S. 2007. Slocum gliders: robust and ready. Journal of Field Robotics 24, 473-485.

Seity Y., Brousseau P., Malardel S., Hello G., Bénard P., Bouttier F., Lac C. \& Masson V. 2011. The AROMEFrance convective-scale operational model. Monthly Weather Review 139, 976-991.

Skogseth R., Haugan P.M. \& Haarpaintner J. 2004. Ice and brine production in Storfjorden from four winters of satellite and in situ observations and modeling. Journal of Geophysical Research-Oceans 109, C10008, doi: 10.1029/2004JC002384.

Skogseth R., Haugan P.M. \& Jakobsson M. 2005. Watermass transformations in Storfjorden. Continental Shelf Research 25, 667-695.

Skogseth R., Sandvik A.D. \& Asplin L. 2007. Wind and tidal forcing on the meso-scale circulation in Storfjorden, Svalbard. Continental Shelf Research 27, 208-227.

Stommel H. 1989. The Slocum mission. Oceanography 2, 2225.

Straneo F. \& Heimbach P. 2013. North Atlantic warming and the retreat of Greenland's outlet glaciers. Nature 504, 36-43.

Sundfjord A., Albretsen J., Kasajima Y., Skogseth R., Kohler J., Nuth C., Skarðhamar J., Cottier F., Nilsen F., Asplin L., Gerland S. \& Torsvik T. 2017. Effects of glacier runoff and wind on surface layer dynamics and Atlantic Water exchange in Kongsfjorden, Svalbard: a model study. Estuarine, Coastal and Shelf Science 187, 260-272.

Sutherland D.A. \& Straneo F. 2012. Estimating ocean heat transports and submarine melt rates in sermilik fjord, Greenland, using lowered acoustic doppler current profiler (LADCP) velocity profiles. Annals of Glaciology 53, 50-58.

Sutherland D.A., Straneo F. \& Pickart R.S. 2014. Characteristics and dynamics of two major Greenland glacial fjords. Journal of Geophysical Research-Oceans 119, 3767-3791. 
Svendsen H., Beszczynska-Møller A., Hagen J.O., Lefauconnier B., Tverberg V., Gerland S., Ørbæk J.B., Bischof K., Papucci C., Zajaczkowski M., Azzolini R., Bruland O., Wiencke C., Winther J. \& Dallmann W. 2002. The physical environment of Kongsfjorden-Krossfjorden, an Arctic fjord system in Svalbard. Polar Research 21, 133-166.

Taylor G.I. 1917. Motion of solids in fluids when the flow is not irrotational. Proceedings of the Royal Society A: Mathematical, Physical and Engineering Sciences 93, 92-113.
Von der Mühll K. 1886. Ueber die Bewegung tropfbarer Flüssigkeiten in Gefässen-Nach Johann Rudolf Merian. (On the motion of drippable liquids in containers, according to Johann Rudolf Merian.) Mathematische Annalen 27, 575-600.

Zhou M., Bachmayer R. \& De Young B. 2015. Working towards seafloor and underwater iceberg mapping with a Slocum glider. In: 2014 IEEE/OES Autonomous Underwater Vehicles (AUV) 2014. Institute of Electrical and Electronics Engineers. 